\title{
Fuel Property, Emission Test, and Operability Results from a Fleet of Class 6 Vehicles Operating on Gas-To-Liquid Fuel and Catalyzed Diesel Particle Filters
}

Teresa L. Alleman, Leslie Eudy

National Renewable Energy Laboratory

Matt Miyasato, Adewale Oshinuga

South Coast Air Quality Management District

Scott Allison, Tom Corcoran

International Truck and Engine Corporation

Sougato Chatterjee, Todd Jacobs Johnson Matthey

Ralph A. Cherrillo, Richard Clark, lan Virrels Shell Global Solutions (US) Inc.

Ralph Nine, Scott Wayne

West Virginia University

Ron Lansing

Yosemite Waters

Copyright @ 2004 SAE International

\begin{abstract}
A fleet of six 2001 International Class 6 trucks operating in southern California was selected for an operability and emissions study using gas-to-liquid (GTL) fuel and catalyzed diesel particle filters (CDPF). Three vehicles were fueled with CARB specification diesel fuel and no emission control devices (current technology), and three vehicles were fueled with GTL fuel and retrofit with Johnson Matthey's CCRT ${ }^{\mathrm{TM}}$ diesel particulate filter. No engine modifications were made.
\end{abstract}

Bench scale fuel-engine compatibility testing showed the GTL fuel had cold flow properties suitable for year-round use in southern California and was additized to meet current lubricity standards. Bench scale elastomer compatibility testing returned results similar to those of CARB specification diesel fuel. The GTL fuel met or exceeded ASTM D975 fuel properties.

Researchers used a chassis dynamometer to test emissions over the City Suburban Heavy Vehicle Route (CSHVR) and New York City Bus (NYCB) cycles. The GTL- fueled vehicles were tested with and without the CDPFs to isolate fuel and aftertreatment effects.

All emission changes are compared to the CARB specification diesel baseline. Over the CSHVR cycle,
GTL fuel (no filter) reduced all regulated emissions, with oxides of nitrogen $\left(\mathrm{NO}_{\mathrm{x}}\right)$ reductions of $8 \%$ and particulate matter (PM) reductions of $33 \%$. Over the NYCB cycle, GTL fuel (no filter) reduced $\mathrm{NO}_{\mathrm{x}}$ and $\mathrm{PM}$ by $16 \%$ and $23 \%$, respectively. Combining GTL and CDPF further reduced all regulated emissions, with $\mathrm{NO}_{\mathrm{x}}$ and PM reductions of $14 \%$ and $99 \%$, respectively, on the CSHVR cycle. Vehicles tested over the NYCB cycle on GTL fuel and CDPF produced $\mathrm{NO}_{x}$ and PM reductions of $20 \%$ and $97 \%$, respectively.

\section{INTRODUCTION}

Gas-to-liquid (GTL) technology has been used for many years to synthesize hydrocarbons from natural gas. Recently, interest has grown in the production of GTL fuels and their emission reduction benefits. Several companies produce or have produced GIL fuels, including Shell, Sasol, ExxonMobil, and others 1

Many studies have examined the impact of GTL fuel on exhaust emissions from light- and heavy-duty vehicles and engines (summarized in Reference 2). In a majority of cases, GTL fuel produced a reduction in regulated emissions (hydrocarbons $[\mathrm{HC}]$, oxides of nitrogen [ $\left.\mathrm{NO}_{\mathrm{x}}\right]$, carbon monoxide [CO], particulate matter [PM]) compared to conventional diesel fuel. 
Much of the emission data reported have come from short-term studies, where the engine/vehicle has been switched to GTL fuel from conventional diesel fuel for the purposes of collecting emission test results. Upon concluding the tests, the engine/vehicle is then switched back to conventional diesel fuel. Thus, the long-term effect of GTL fuel on engine systems has not been adequately quantified.

\section{FUEL PROPERTY TESTING}

Previous studies of GTL diesel fuel do not always list complete fuel properties or test methods. ${ }^{2}$ The fuel used in this study was tested to determine physical and chemical properties. In addition, researchers performed elastomer compatibility testing to characterize the impact of GTL fuel on fuel system elastomers.

FUEL PRODUCTION TECHNOLOGY - Shell Global Solutions (US) Inc. provided the fuel that was used for fuel property and emission testing, and on-road use.

The SMDS (Shell Middle Distillate Synthesis) process is well documented, so only a brief description is offered here. ${ }^{3}$ The process is illustrated in Figure 1 . The process was developed at Shell Research \& Technology Centre Amsterdam and is comprised essentially of three stages:

Manufacture of synthesis gas (hydrogen + carbon monoxide-with a $\mathrm{H}_{2}$ : $\mathrm{CO}$ ratio of approximately two) from natural gas by non-catalytic auto-thermal partial oxidation using, for example, the Shell Gasification Process.

Wax synthesis from $\mathrm{CO}+\mathrm{H}_{2}$ by Heavy Paraffin Synthesis (HPS), followed by flash distillation to separate light ends (e.g., liquefied petroleum gas).

Cracking of wax to distillates by Heavy Paraffin Conversion (HPC), where the boiling range and quality of the products can be adjusted to produce either kerosene or atmospheric gas oil (diesel).

A recent modification to this process, designated as SMDS-2 offers an improved HPS (Heavy Paraffin Synthesis) catalyst, which will enable the manufacturers to increase production capacity considerably. In addition, adjusting the severity in the hydrocracking/isomerization (HPC) stage allows control of the $n$ - to iso- paraffin ratio in the final product.

Figure 1. Schematic illustration of Shell SMDS process.

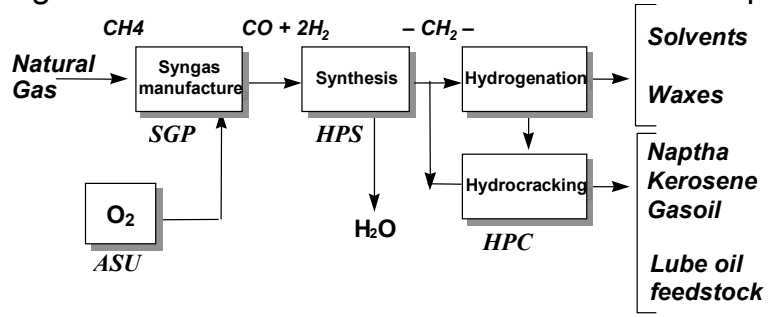

FUEL PROPERTY TEST RESULTS - The fuel was tested for a wide range of properties, such as composition, energy content, cold flow properties, and elastomer compatibility. All fuel property testing was performed at Southwest Research Institute in San Antonio, TX.

Except for elastomer compatibility, which will be discussed separately, the test results are compiled in Table 1. Where applicable, the ASTM D975 specification is also listed.

The fuel composition was tested through elemental testing and hydrocarbon determination. GTL fuel is composed of carbon and hydrogen. The fuel $\mathrm{H} / \mathrm{C}$ ratio is about 2.1 , about $16 \%$ greater than conventional diesel fuel. The high $\mathrm{H} / \mathrm{C}$ ratio is due to the near zero aromatic content of the GTL diesel fuel. ${ }^{4}$ As with most GTL fuels, the Shell GTL has near zero sulfur content.

The very low aromatic content and/or the high $\mathrm{H} / \mathrm{C}$ ratio of diesel fuel have been shown to reduce $\mathrm{NO}_{x}$ and $\mathrm{PM}$ emissions in previous studies. ${ }^{5,6,7}$ Thus, testing with GTL fuel is likely to result in reductions in $\mathrm{NO}_{x}$ and $\mathrm{PM}$ emissions.

Fuel sulfur reductions also result in PM emission reductions, though with diminishing returns as sulfur content becomes very low. ${ }^{6}$ In newer technology engines, the near zero sulfur content of GTL fuel may prove more beneficial by enabling sulfur sensitive emission control devices.

GTL fuels have reduced densities compared to conventional diesel fuels, ${ }^{2}$ which have been shown to reduce the PM emission in older technology engines. ${ }^{6,7}$ Low density fuels, such as GTL fuel, may alter the fuel mass flow rates. ${ }^{7}$ Previous GTL fuel studies have not noted adverse effects on engine operation as a result of the lower fuel density. ${ }^{9,10,11}$

The cetane number of GTL fuels is most often reported as $>74$, much higher than conventional diesel fuels. ${ }^{12}$ GTL fuel is composed almost wholly of paraffins. Nparaffins are known to have very high cetane numbers, while iso-paraffins have lower cetane numbers. ${ }^{13}$

Increasing cetane number has been linked to a decrease or no change in $\mathrm{NO}_{x}$ emissions. The effect appears to be depend on engine model year, with a less prominent effect on newer technology engines. ${ }^{5,6,7}$ 
Table 1. Fuel properties of Shell GTL fuel.

\begin{tabular}{|c|c|c|c|}
\hline Property & Test Method & Results & $\begin{array}{c}\text { ASTM D975 } \\
\text { Specification }\end{array}$ \\
\hline Density, $\mathrm{g} / \mathrm{mL}$ & ASTM D4052 & 0.7838 & \\
\hline API Gravity & ASTM D287 & 49 & \\
\hline Viscosity, cSt at $40^{\circ} \mathrm{C}$ & ASTM D445 & 3.468 & $1.9-4.1$ \\
\hline Flash Point, ${ }^{\circ} \mathrm{C}$ & ASTM D93 & 89 & 52 minimum \\
\hline Sulfur, ppm & ASTM D5453 & 0.5 & 500 maximum \\
\hline Carbon to Hydrogen ratio & & 2.13 & \\
\hline SFC Aromatics, mass $\%$ & \multirow{4}{*}{ ASTM D5186 } & & \\
\hline Monoaromatics & & 1.4 & \\
\hline Polynuclear aromatics & & $<0.1$ & \\
\hline Total aromatics & & 1.4 & \\
\hline Hydrocarbon types, vol\% & \multirow{4}{*}{ ASTM D1319 } & & \\
\hline Aromatics & & 1.0 & 35 maximum \\
\hline Olefins & & 1.0 & \\
\hline Saturates & & 98.0 & \\
\hline Heat of combustion, BTU/lb & \multirow{3}{*}{ ASTM D240 } & & \\
\hline Gross & & 20,246 & \\
\hline Net & & 18,878 & \\
\hline Cetane Number & ASTM D613 & 79.5 & 40 minimum \\
\hline & IQT & 77.9 & \\
\hline Autoignition temperature, ${ }^{\circ} \mathrm{C}$ & \multirow{2}{*}{ ASTM E659 } & 207.2 & \\
\hline Ignition delay time, seconds & & 141.3 & \\
\hline Distillation, ${ }^{\circ} \mathrm{C}$ & \multirow{6}{*}{ ASTM D86 } & & \\
\hline IBP & & 208.9 & \\
\hline T10 & & 246.7 & \\
\hline T50 & & 299.0 & \\
\hline T90 & & 331.1 & $282-338$ \\
\hline FBP & & 343.2 & \\
\hline Cloud Point, ${ }^{\circ} \mathrm{C}$ & ASTM D2500 & 1 & \\
\hline Pour Point, ${ }^{\circ} \mathrm{C}$ & ASTM D97 & -6 & \\
\hline Cold filter plugging point (CFPP), ${ }^{\circ} \mathrm{C}$ & IP 309 & -1 & \\
\hline Low temperature flow test (LTFT), ${ }^{\circ} \mathrm{C}$ & ASTM D4539 & -2 & \\
\hline Water and Sediment & ASTM D1796 & $<0.02$ & -- \\
\hline Copper Corrosion & ASTM D130 & $1 \mathrm{~A}$ & 3 maximum \\
\hline Peroxide number, $\mathrm{mg} / \mathrm{kg}$ & ASTM D3703 & $<1$ & \\
\hline Gum content, $\mathrm{mg} / 100 \mathrm{~mL}$ & ASTM D381 & 5.9 & \\
\hline Ash, mass \% & ASTM D482 & $<0.001$ & 0.01 maximum \\
\hline Carbon residue, $\%$ mass & ASTM D524 & 0.03 & 0.15 maximum \\
\hline Acid number, $\mathrm{mg}$ & ASTM D664 & $<0.5$ & \\
\hline Accelerated stability, $\mathrm{mg} / 100 \mathrm{~mL}$ & ASTM D2274 & 0.4 & \\
\hline $\begin{array}{l}\text { High temperature stability, } \\
180 \mathrm{~min}, \text { Avg \% Reflectance }\end{array}$ & ASTM D6468 & 100 & \\
\hline $\begin{array}{l}\text { Scuffing Load Ball-on-Cylinder } \\
\text { Lubricity Evaluator, scuff load, g }\end{array}$ & ASTM D6078 & $2,750^{*}$ & \\
\hline $\begin{array}{l}\text { High Frequency Reciprocating Rig, } \\
\text { wear scar, mm }\end{array}$ & ASTM D6079 & $0.395^{\star}$ & \\
\hline
\end{tabular}

* Results from subsequent test.

Highly paraffinic GTL fuels may have cold flow properties that are not acceptable for operation throughout the United States. The test fleet in this project operated exclusively in southern California (metro Los Angeles area), where the cold flow operability of GTL fuel was not an issue.

Other properties, such as gum, ash, and water and sediment are in line with other diesel fuels and are not expected to impact operations. A reduced T90/T95 temperature has been shown to have a small impact on emissions. ${ }^{7,14}$ For GTL fuel, any impact based on T90/T95 temperature is likely obscured by other fuel properties such as paraffin content and cetane number.

Typically, unadditized GTL fuels have poor lubricities due to a lack of polar molecules, but respond well to additives. ${ }^{9,15}$ The fuel used in this work was additized.

BENCH ELASTOMER COMPATIBILITY TEST RESULTS - Bench scale elastomer testing was used to complement the real-world data gathered from 
introduction of GTL fuels into a vehicle fleet for many months.

International Truck and Engine Corporation contributed several sets of new elastomers for the compatibility testing. The elastomers were from the DT466 engine and were identical to those found in the study vehicles. The GTL fuel had the properties listed in Table 1. The commercial CARB specification diesel fuel was a typical diesel fuel meeting CARB diesel specifications. Properties for this fuel are in Table 2.

Table 2. CARB specification diesel fuel properties used for elastomer testing.

\begin{tabular}{|c|c|c|}
\hline Property & Test Method & Results \\
\hline Density, $\mathrm{g} / \mathrm{mL}$ & ASTM D4052 & 0.8299 \\
\hline API Gravity & ASTM D287 & 38.9 \\
\hline Flash Point, ${ }^{\circ} \mathrm{C}$ & ASTM D93 & 70 \\
\hline Sulfur, ppm & ASTM D5453 & 153 \\
\hline Carbon, mass $\%$ & \multirow{3}{*}{ ASTM D5291 } & 86.42 \\
\hline Hydrogen, mass $\%$ & & 13.64 \\
\hline Oxygen, mass $\%$ by difference & & $<0.01$ \\
\hline SFC Aromatics, mass $\%$ & \multirow{3}{*}{ ASTM D5186 } & \\
\hline Polynuclear Aromatics & & 3.4 \\
\hline Total Aromatics & & 21.8 \\
\hline Hydrocarbon types, vol\% & \multirow{4}{*}{ ASTM D1319 } & \\
\hline Aromatics & & 22.3 \\
\hline Olefins & & 2.7 \\
\hline Saturates & & 75.0 \\
\hline Heat of Combustion, BTU/lb & \multirow{3}{*}{ ASTM D240 } & \\
\hline Gross & & 19,749 \\
\hline Net & & 18,505 \\
\hline Cetane Number & ASTM D613 & 55.4 \\
\hline Cloud Point, ${ }^{\circ} \mathrm{C}$ & ASTM D2500 & -9 \\
\hline Pour Point, ${ }^{\circ} \mathrm{C}$ & ASTM D97 & -26 \\
\hline Distillation, ${ }^{\circ} \mathrm{C}$ & \multirow{6}{*}{ ASTM D86 } & \\
\hline IBP & & 176.4 \\
\hline T10 & & 201.8 \\
\hline T50 & & 261.4 \\
\hline T90 & & 323.6 \\
\hline FBP & & 348.4 \\
\hline Gum Content, mg/100mL & ASTM D381 & 13.2 \\
\hline
\end{tabular}

Elastomer testing included hardness, volume, radial thickness changes, elongation, reversion, bend testing, and sediment observation. Three identical elastomers were used for each test, under each of the three test conditions in addition to a set for the control case (no fuel exposure). The elastomers were in new, unused condition prior to the start of the tests.

1. CARB specification diesel fuel at $60^{\circ} \mathrm{C}$ for 1,000 hours

2. GTL fuel at $60^{\circ} \mathrm{C}$ for 1,000 hours

3. CARB diesel fuel at $60^{\circ} \mathrm{C}$ for 500 hours, followed by GTL fuel at $60^{\circ} \mathrm{C}$ for 500 hours, 1,000 hours total

The CARB specification diesel fuel exposure followed by GTL fuel exposure was selected to investigate the effect of changing fuels on elastomer properties. The impact of diesel fuel aromatic compounds on the swell of elastomers has been previously documented. ${ }^{16}$ Diesel fuel properties may have a lesser effect on fluorocarbon elastomers than gasoline, but investigation is still needed. ${ }^{17}$

Four types of elastomers were tested and indicated as $A, B, C 1$, and C2. Elastomer A was a seal, composed of Viton, VA-154-95. Elastomers B and C1 were also seals, composed of Viton, VA-153-90. Elastomer C2 was a cushion, composed of hydrogenated nitrile buna rubber (HNBR). The control results were collected from elastomers not exposed to fuel.

Results of the bench scale elastomer testing are in Appendix A-1. After exposure to the fuel(s), no sediment was recorded for any of the four types of elastomers, nor was any reversion observed. The elastomers also all passed the bend test. The reported hardness changes were minor for all four elastomers under each of the three test conditions.

Elastomers A, B, and C1 did not show an appreciable change in volume after exposure to any of the test fuels. Elastomer $\mathrm{C} 2$ showed some swelling upon exposure to the CARB specification diesel fuel, likely due to the $22 \%$ aromatic content of the fuel. However, no swelling was observed for $\mathrm{C} 2$ during exposure to the GTL alone or the CARB specification diesel followed by the GTL fuel.

The radial thickness of the elastomers did not change with exposure to the test fuels. This is an interesting point to note, as elastomer $\mathrm{C} 2$ swelled with exposure to the CARB specification diesel fuel. The increase in volume of elastomer $\mathrm{C} 2$ was not swelling along the radial axis, but an increase in the height of the elastomer.

A simple statistical analysis was performed on the elongation results. The results were analyzed using a two-tailed t-test, assuming equal variances, at the $95 \%$ confidence level. The p-values are shown in Table 3. Note that the symbol CARB $\rightarrow$ GTL indicates exposure to condition 3 or CARB specification diesel followed by GTL fuel.

There were no significant changes in the elongation of elastomer A, either compared to the control or between the fuels. For the most part, no changes in the elongation of elastomer B were observed. However, between the control and the GTL fuel and the control and the CARB specification diesel, small changes in the elongation for elastomer $B$ were noted. No changes were recorded for $\mathrm{C} 1$.

For $\mathrm{C} 2$, only one small change was recorded for the CARB specification diesel compared to the CARB $\rightarrow G T L$ exposure. Elastomer C2 showed a higher overall variability compared to the other elastomers, possibly due to the chemical composition of the HNBR. Unfortunately, more detailed information about the degree of hydrogenation and acetonitrile content of $\mathrm{C} 2$ is not available. 
All four elastomers held up well to the bench testing that was performed in this study. Based on the results from this portion, there was little concern about introducing the GTL fuel to the fleet vehicles. Additionally, no vehicle preparation was performed prior to the switch, such as replacing the elastomers.

Table 3. P-values for elastomer elongation results.

\begin{tabular}{|c|c|c|c|}
\hline Elastomer & $\begin{array}{l}\text { Fuels } \\
\end{array}$ & P-value & Significant? \\
\hline A & Control to GTL & 0.407 & No \\
\hline A & $\begin{array}{c}\text { Control to CARB } \\
\rightarrow \mathrm{GTL}\end{array}$ & 0.289 & No \\
\hline A & Control to CARB & 0.348 & No \\
\hline A & $\begin{array}{c}\text { GTL to } \\
\text { CARB } \rightarrow \text { GTL }\end{array}$ & 0.896 & No \\
\hline $\mathrm{A}$ & GTL to CARB & 0.993 & No \\
\hline A & $\begin{array}{c}\mathrm{CARB} \rightarrow \mathrm{GTL} \text { to } \\
\mathrm{CARB}\end{array}$ & 0.889 & No \\
\hline $\mathrm{B}$ & Control to GTL & 0.033 & Yes \\
\hline B & $\begin{array}{c}\text { Control to } \\
\text { CARB } \rightarrow \text { GTL }\end{array}$ & 0.251 & No \\
\hline $\mathrm{B}$ & Control to CARB & 0.059 & Maybe \\
\hline B & $\begin{array}{c}\text { GTL to } \\
\text { CARB } \rightarrow \text { GTL }\end{array}$ & 0.187 & No \\
\hline $\mathrm{B}$ & GTL to CARB & 0.776 & No \\
\hline B & $\begin{array}{c}\text { CARB } \rightarrow \text { GTL to } \\
\text { CARB }\end{array}$ & 0.306 & No \\
\hline $\mathrm{C} 1$ & Control to GTL & 0.818 & No \\
\hline C1 & $\begin{array}{c}\text { Control to } \\
\text { CARB } \rightarrow \text { GTL }\end{array}$ & 0.556 & No \\
\hline $\mathrm{C} 1$ & Control to CARB & 0.678 & No \\
\hline C1 & $\begin{array}{c}\text { GTL to } \\
\text { CARB } \rightarrow \text { GTL }\end{array}$ & 0.132 & No \\
\hline C1 & GTL to CARB & 0.346 & No \\
\hline C1 & $\begin{array}{c}\text { CARB } \rightarrow \text { GTL to } \\
\text { CARB }\end{array}$ & 0.864 & No \\
\hline $\mathrm{C} 2$ & Control to GTL & 0.745 & No \\
\hline C2 & $\begin{array}{c}\text { Control to } \\
\text { CARB } \rightarrow \text { GTL }\end{array}$ & 0.137 & No \\
\hline $\mathrm{C} 2$ & Control to CARB & 0.745 & No \\
\hline $\mathrm{C} 2$ & $\begin{array}{c}\text { GTL to } \\
\text { CARB } \rightarrow \text { GTL }\end{array}$ & 0.013 & Yes \\
\hline $\mathrm{C} 2$ & GTL to CARB & 0.264 & No \\
\hline $\mathrm{C} 2$ & $\begin{array}{c}\text { CARB } \rightarrow \text { GTL to } \\
\text { CARB }\end{array}$ & 0.043 & Yes \\
\hline
\end{tabular}

\section{FLEET PROPERTIES}

Yosemite Waters in Fullerton, CA provided the study vehicles for this project. The participating vehicles were similar and operated out of a single location. Vehicle and engine specifications are shown in Table 4.

Each Yosemite Waters vehicle operates on a dedicated 10-day route with varying degrees of city and freeway driving. Thus, the driving characteristics of each vehicle were somewhat unique (see Table 5). Also shown in Table 5 are the vehicles selected to operate on CARB specification diesel fuel and the vehicles selected to operate on GTL fuel with the emission control devices.

One factor in designating the vehicles as "baseline" or "test" was the percentage of highway miles. Vehicles
201 and 204 have the lowest percentage of highway miles. If these vehicles were both "baseline" or both "test", the real-world fuel economy might be biased, as lower fuel economy is recorded during city driving. Thus, vehicle 201 was in the "baseline" group and vehicle 204 was in the "test" group.

Table 4. Vehicle and engine specifications for Yosemite Waters test fleet.

\begin{tabular}{|l|l|}
\hline Vehicle & \\
\hline Manufacturer & International \\
\hline Model number & 4300-DT466 \\
\hline Body manufacturer & Hackney \\
\hline Vehicle activity & Pickup and delivery \\
\hline Transmission type & 5-speed automatic \\
\hline Transmission manufacturer & Allison \\
\hline Transmission Model & 2000 \\
\hline Engine & \\
\hline Manufacturer & International \\
\hline Engine & DT466 \\
\hline Configuration & Inline 6 cylinder \\
\hline Model year & 2001 \\
\hline Peak Power & $195 \mathrm{hp} \mathrm{@} \mathrm{2,300} \mathrm{rpm}$ \\
\hline Peak Torque & $520 \mathrm{ft}-\mathrm{lb}$ \\
\hline
\end{tabular}

Table 5. Driving characteristics for test vehicles in Yosemite Waters fleet.

\begin{tabular}{|c|c|c|c|}
\hline Vehicle & $\begin{array}{c}\text { Fuel/ } \\
\text { Emission } \\
\text { Control }\end{array}$ & $\begin{array}{c}\text { \% Highway } \\
\text { Miles over } \\
\text { 10-day cycle }\end{array}$ & $\begin{array}{c}\text { Total Miles } \\
\text { Driven over } \\
\text { 10-day cycle }\end{array}$ \\
\hline 201 & CARB, None & 36 & 532 \\
\hline 202 & CARB, None & 75 & 752 \\
\hline 203 & CARB, None & 74 & 1,030 \\
\hline 204 & $\begin{array}{c}\text { GTL, CCRT } \\
\text { filter }\end{array}$ & 61 & 680 \\
\hline 205 & $\begin{array}{c}\text { GTL, CCRT } \\
\text { filter }\end{array}$ & 82 & 667 \\
\hline 206 & $\begin{array}{c}\text { GTL, CCRT } \\
\text { filter }\end{array}$ & 77 & 837 \\
\hline
\end{tabular}

The other vehicles had more similar percentages of highway miles and were divided so that consecutive vehicle numbers were in the same category (i.e. 201, 202, and 203 were baseline).

\section{EMISSION CONTROL DEVICES}

The test vehicles were operated on GTL fuel for at least two weeks prior to installing the emission control devices to ensure no residual CARB specification diesel fuel remained in the fuel system.

Johnson Matthey supplied the emission control devicesCCRT filters (Catalyzed Continuously Regenerating Technology). The CCRT filter is a diesel oxidation catalyst followed by a wall-flow catalyzed soot filter. ${ }^{22}$ Testing has shown that the CCRT filter has good low temperature performance.

The good low temperature performance was an important characteristic in selecting the CCRT filter for 
this project. Because vehicle 204 had a low percentage of highway miles compared to the other fleet vehicles and subsequently, a low average exhaust temperature (average exhaust temperature $\sim 210^{\circ} \mathrm{C}$ ), it was selected to be the first vehicle retrofit.

The exhaust temperature and pressure of vehicle 204 was monitored for several months to insure the filter performance was acceptable. Exhaust pressure and temperature histograms collected over several months showed stable filter operation. After analyzing this data, vehicles 205 and 206 were retrofit as well.

\section{DATALOGGER RESULTS}

On-board dataloggers were used to evaluate the efficacy of the CCRT filters by continuously measuring exhaust backpressure and temperature over the road.

As shown in Table 5, vehicle 204 travels on the highway $61 \%$ of the time during its 10 -day route. Of the three test vehicles, the average exhaust temperature of this vehicle is expected to be the lowest. Figure 2 presents a histogram of the data collected from vehicle 204 during the project. The shaded area indicates that the vehicle has an exhaust temperature above about $210^{\circ} \mathrm{C}$ for $40 \%$ of its operating time. Similar histograms are shown in Figures 3 and 4 for vehicles 205 and 206. The $40 \%$ cutpoint temperature for vehicles 205 and 206 is much higher than for vehicle $204\left(\sim 230^{\circ} \mathrm{C}\right.$ and $\sim 240^{\circ} \mathrm{C}$, respectively).

Figure 2. Exhaust temperature histogram for vehicle 204 from January 2003 through June 2004.

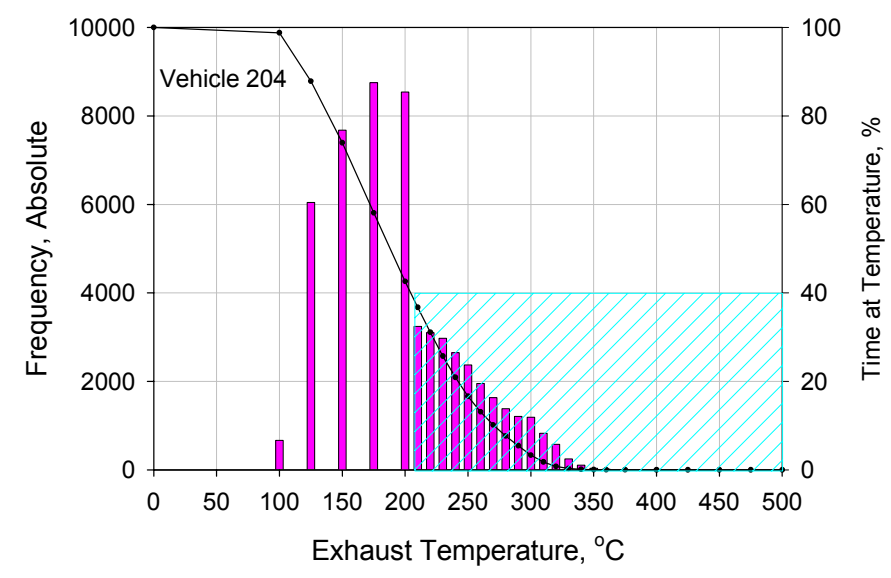

Figure 3. Exhaust temperature histogram for vehicle 205 from December 2003 through June 2004.

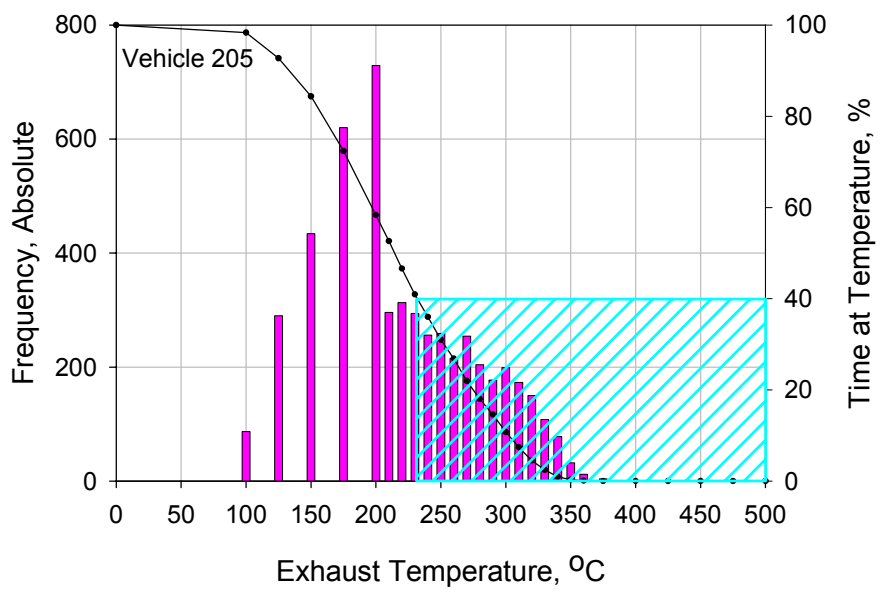

Figure 4. Exhaust temperature histogram for vehicle 206 from December 2003 through June 2004.

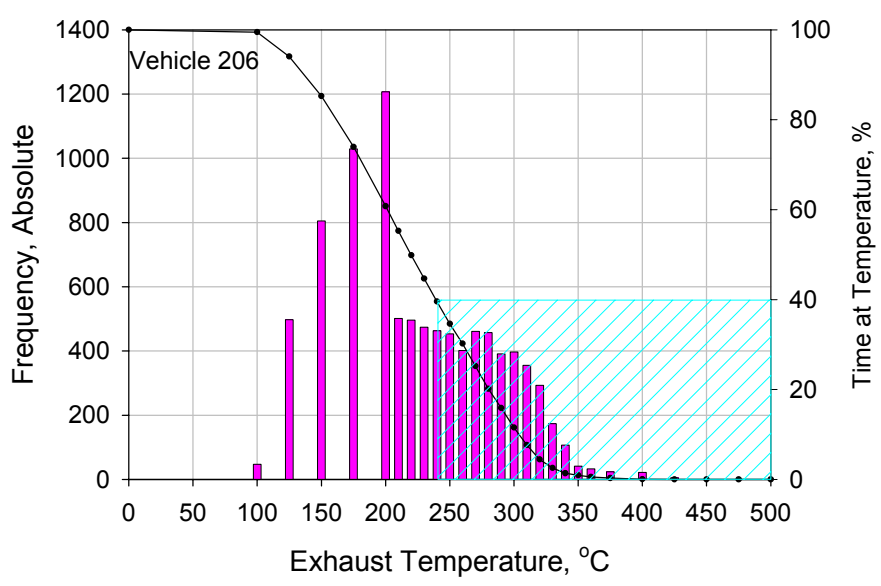

The peak exhaust backpressure data can be used to show if filter performance is deteriorating over time. As the filter becomes plugged, the peak backpressure should increase. Figures 5, 6, and 7 illustrate the peak backpressure for Yosemite Waters vehicles 204, 205, and 206. The backpressure has been very constant over the study period, indicating good filter operation. 
Figure 5. Peak backpressure for vehicle 204 from January 2003 through June 2004.

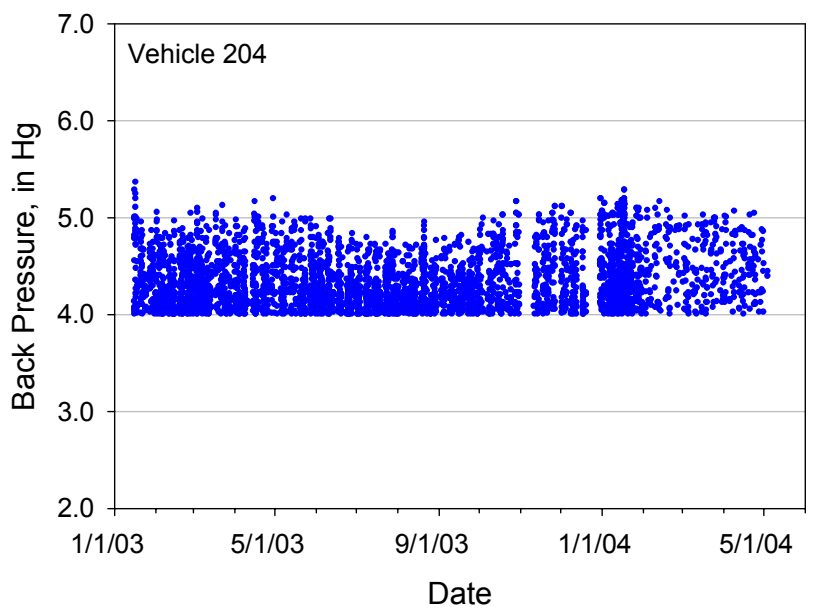

Figure 6. Peak backpressure for vehicle 205 from December 2003 through June 2004.

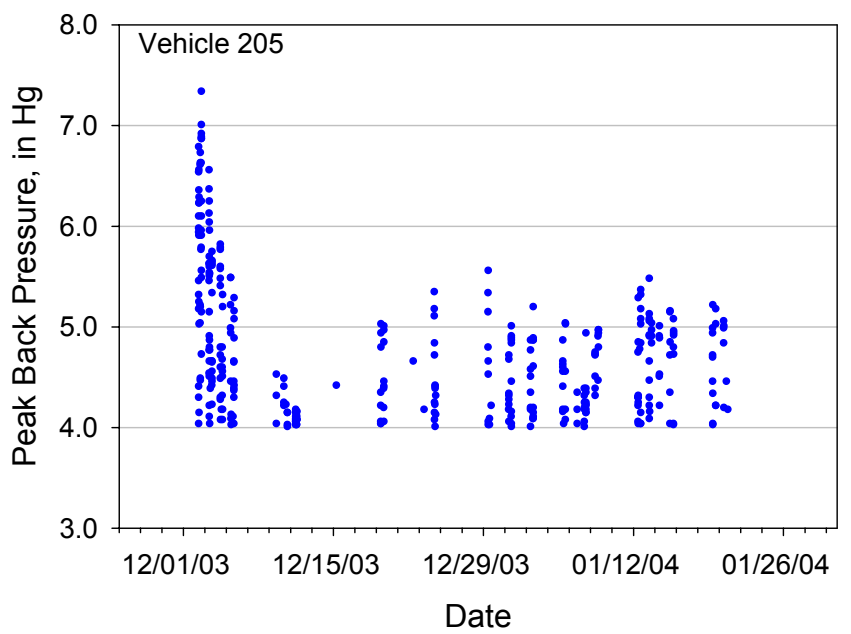

Figure 7. Peak backpressure measurements for vehicle 206 from December 2003 through June 2004.

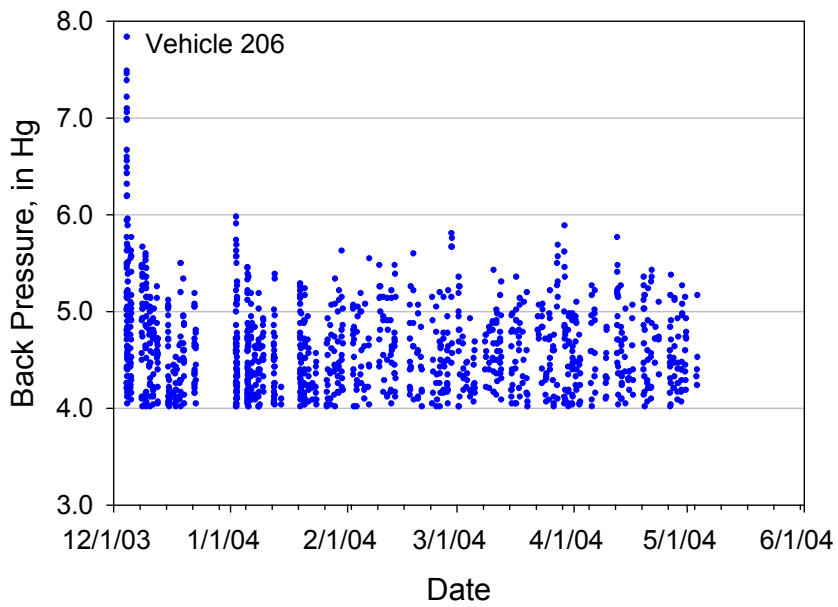

\section{CHASSIS EMISSION COLLECTION}

West Virginia University collected chassis exhaust emissions for the six study vehicles. The West Virginia University Transportable Vehicle Emissions Testing Laboratories were constructed to gather emissions data from in-use heavy-duty vehicles. Detailed information pertaining to the design and operation of the laboratories has been previously published. ${ }^{18,19,20}$

Each laboratory is based around two trailers, one trailer contains rollers, flywheels, and power absorbers for the dynamometer function, and the second trailer houses the controls and emissions measurement equipment. The vehicle to be tested is driven onto the chassis dynamometer and positioned on two sets of rollers (Figure 8). The outer wheels of the dual wheel set on each side of the vehicle are removed and replaced with hub adapters that couple the drive axle directly to the dynamometer units on each side of the vehicle. (See Figure 9).

Each dynamometer unit consists of a power absorber and a set of selectable flywheels, which consist of a series of discs to allow simulation of an inertial load equivalent to a gross vehicle weight of up to 60,000 pounds in 250 pound increments. During the test cycle, torque cells and speed transducers in the power absorber drive train measure the vehicle load and speed. The vehicle can be driven through a wide range of available computerized test cycles to simulate either transient or steady state driving conditions.

Figure 8. Photo of Yosemite Waters Vehicle No. 201 on WVU Transportable Vehicle Emissions Testing Laboratory.

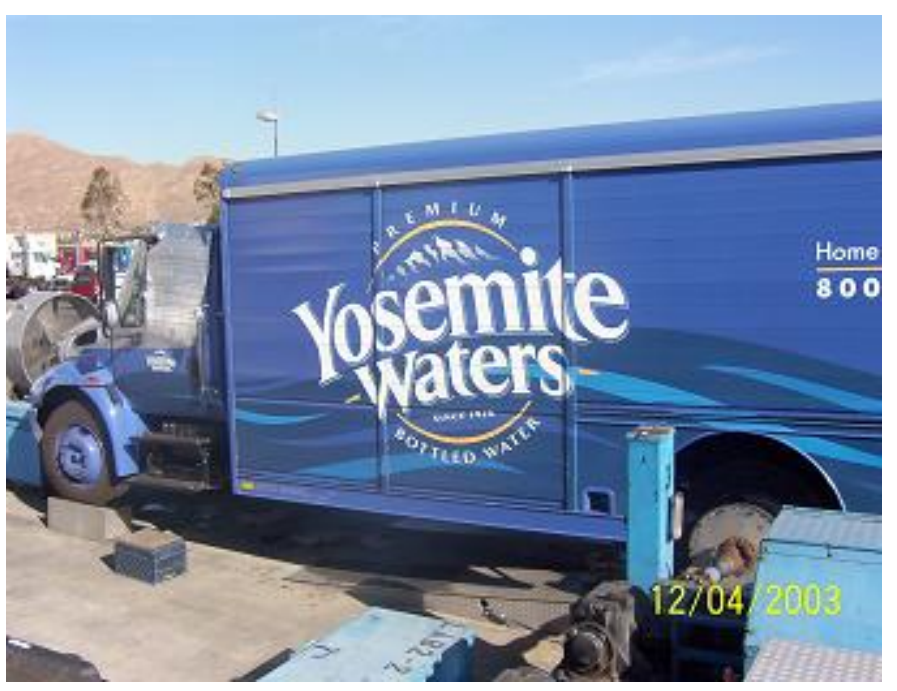


Figure 9. Close-up photo of hub adapters coupled to drive axle.

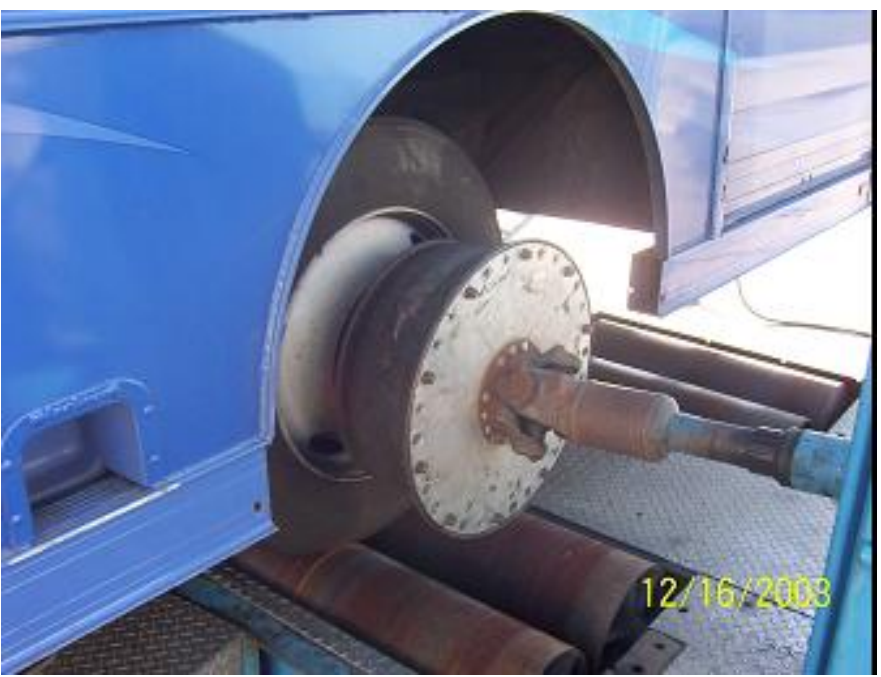

The exhaust from the tail pipe of the test vehicle is ducted to a full-scale dilution tunnel measuring $45 \mathrm{~cm}$ in diameter and $6.1 \mathrm{~m}$ in length. The exhaust is mixed with air and the quantity of diluted exhaust is measured precisely by a critical flow venturi system (CVS).

The diluted exhaust is analyzed using non-dispersive infra-red analyzers for $\mathrm{CO}$ and $\mathrm{CO}_{2}$, and chemiluminescent detection for $\mathrm{NO}_{x}$. Hydrocarbons are analyzed using a heated flame ionization detector. The gaseous data are available as continuous concentrations throughout the test, and the product of concentration and dilution tunnel flow are integrated to yield emissions in units of grams per mile $(\mathrm{g} / \mathrm{mi})$. Particulate matter is collected using 70-mm fluorocarbon coated glass fiber filter media and is determined gravimetrically. Fuel efficiencies are determined using a carbon balance and exhaust emissions data.

Vehicles were tested over a two-week period in December 2003. The test matrix is shown in Table 6 . Testing was conducted over two cycles-the City Suburban Heavy Vehicle Route (CSHVR) and the New York City Bus Cycle (NYCB). The cycles designated by (2) indicate the cycle was run as a "double". In a "double" cycle, the original test cycle is run twice, backto-back without interruption, on a single set of filter media. This ensures that an adequate mass of PM is collected for measurement.

The CSHVR cycle, shown in Figure 10 , is a highly transient cycle with about $10 \%$ of the cycle spent at idle conditions. In contrast, the NYCB cycle (Figure 11) spends over $65 \%$ of the cycle at idle, with much less transient driving. These cycles were selected to test the fuel and emission control systems over a highly transient and a stop-and-go type cycle (CSHVR and NYCB, respectively).
Table 6. Vehicle matrix for chassis dynamometer testing.

\begin{tabular}{|c|c|c|c|}
\hline Vehicle & $\begin{array}{c}\text { Fuel/Emission } \\
\text { Control }\end{array}$ & Cycle 1 & Cycle 2 \\
\hline 201 & CARB, None & CSHVR & NYCB \\
\hline 202 & CARB, None & CSHVR & NYCB \\
\hline 203 & CARB, None & CSHVR & NYCB \\
\hline 204 & GTL, None & CSHVR & NYCB \\
\hline 204 & GTL, CCRT filter & CSHVR(2) & NYCB(2) \\
\hline 205 & GTL, None & CSHVR & NYCB \\
\hline 205 & GTL, CCRT filter & CSHVR(2) & NYCB(2) \\
\hline 206 & GTL, None & CSHVR & NYCB \\
\hline 206 & GTL, CCRT filter & CSHVR(2) & NYCB(2) \\
\hline \multicolumn{4}{|r}{}
\end{tabular}

Figure 10. Schematic of CSHVR driving cycle.

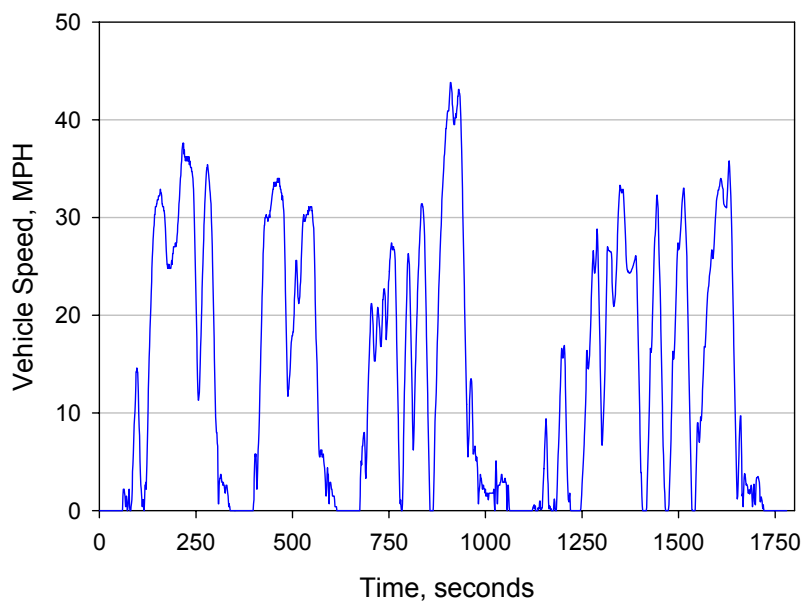

Figure 11. Schematic of NYCB driving cycle.

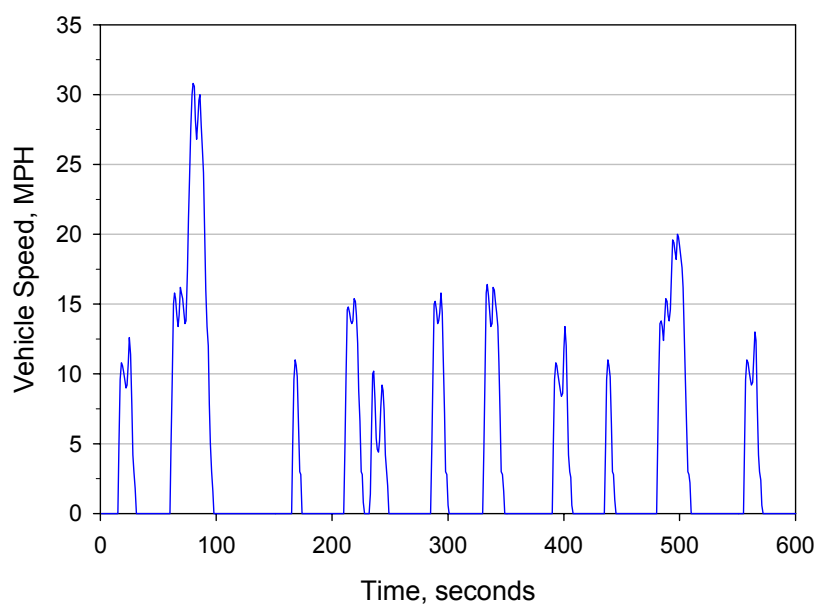

\section{EMISSIONS RESULTS}

Detailed emission test results are presented in Appendix A-2. Vehicle 204 operated with the CCRT filter for 11 months (January 2003 through December 2003). Vehicles 205 and 206 were retrofit in early December 2003. The emission results for the GTL fuel with the 
CCRT filter will be discussed as the average over all three vehicles.

The error bars on the following figures are one confidence interval. The error bars on these figures were generated from the estimated emissions as part of the statistical analysis described in Appendix A-3. Statistical significance of the emission results will be presented later in this paper. Statistical significance of the emissions should not be estimated by overlap of the error bars presented in the figures.

\section{REGULATED EMISSIONS}

CSHVR cycle - Tests conducted with the CARB specification diesel fuel served as the baseline for these results. Changing to GTL fuel (no filter or engine out) from the CARB specification diesel fuel resulted in reductions of all regulated emissions. $\mathrm{HC}$ and $\mathrm{CO}$ emission reductions were $58 \%$ and $10.6 \%$, respectively (see Figure 12).

A $33 \%$ reduction in the PM emission was recorded. Researchers expect that the reduction in the PM emission was due to a reduction in the soot portion of the PM, as noted in previous work. ${ }^{21} \mathrm{~A} \mathrm{NO}_{\mathrm{x}}$ emission reduction of $8.8 \%$ was observed with the GTL fuel (engine out) compared to the CARB specification diesel fuel (engine out). This reduction is in line with previous estimates for GTL fuel in diesel engines. ${ }^{0}$

Combining the GTL fuel with the CCRT filter resulted in larger emission reductions for the regulated pollutants. The average reductions in $\mathrm{HC}, \mathrm{CO}$, and $\mathrm{PM}$ for all three vehicles $(204,205$, and 206$)$ were greater than $99 \%$.

With the CCRT filter, the $\mathrm{NO}_{x}$ emissions were reduced $14 \%$ compared to CARB specification diesel fuel tests. This reduction is likely due to conversion of a small amount of $\mathrm{NO}_{2}$ to $\mathrm{N}_{2}$ over the filter. ${ }^{22}$

Figure 12. CSHVR Regulated Emissions Results.

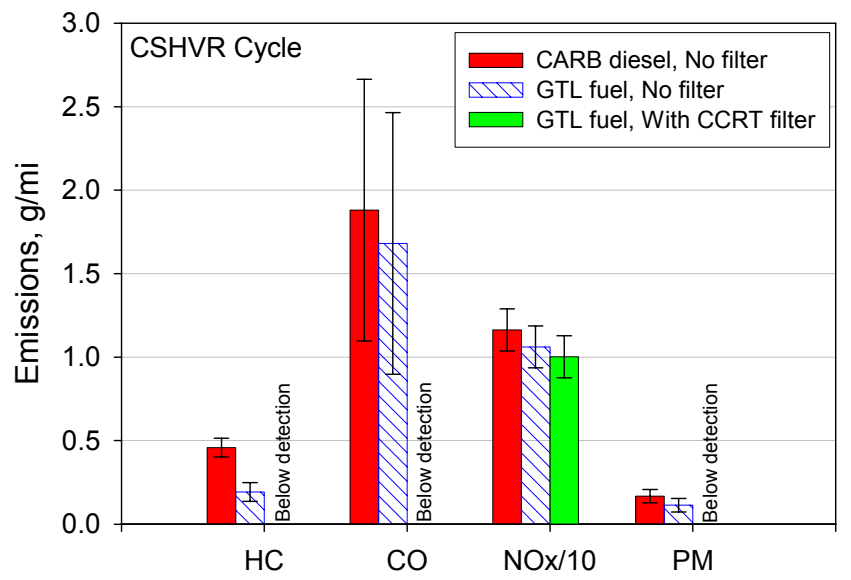

NYCB Test Results - As with the CSHVR cycle, all results are compared to the CARB specification diesel fuel baseline. Over the NYCB cycle, there was no change in the $\mathrm{CO}$ emission $(+0.81 \%)$, but large reductions in $\mathrm{HC}$ and $\mathrm{PM}$ emissions $(69 \%$ and $23 \%$, respectively). The $\mathrm{NO}_{x}$ emissions were reduced by $13 \%$ over the NYCB cycle. The emissions results are illustrated in Figure 13.

The effect of the GTL fuel and the CCRT filter on emissions was significant. $\mathrm{HC}$ and $\mathrm{CO}$ emissions were reduced to below detection limits. A $97 \%$ reduction in the PM emission was recorded. A slight additional $\mathrm{NO}_{x}$ decrease was detected $(17 \%$ reduction compared to baseline), attributed to the $\mathrm{NO}_{2}$ to $\mathrm{N}_{2}$ conversion.

Figure 13. NYCB Regulated Emissions Results.

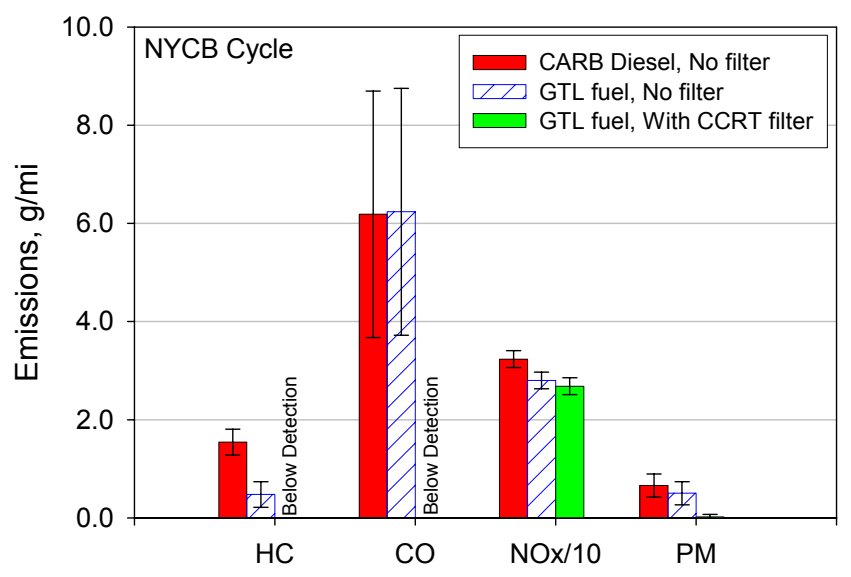

\section{CALCULATED $\mathrm{NO}_{2}$ EMISSIONS}

The $\mathrm{NO}_{2}$ emissions were calculated using a dual $\mathrm{NO}_{x}$ analyzer method. The method employs two unique $\mathrm{NO}_{x}$ analyzers, one operated in the $\mathrm{NO}_{x}$ mode, while the other analyzer operates in the NO mode. The difference between $\mathrm{NO}_{\mathrm{x}}$ emission and $\mathrm{NO}$ emission is the calculated $\mathrm{NO}_{2}$ emission. The technique and limitations have been previously described. ${ }^{23}$ In Figures 14 and 15, the shaded bar on the left represents the calculated $\mathrm{NO}_{2}$ emission, while the solid bar on the right shows the $\mathrm{NO}_{x}$ emission. The error bars are the confidence interval, as described above.

CSHVR CYCLE - Figure 14 presents the $\mathrm{NO}_{\mathrm{x}}$ and calculated $\mathrm{NO}_{2}$ emissions from the Yosemite Waters vehicles over the CSHVR cycle. As illustrated in the figure, the calculated $\mathrm{NO}_{2}$ for the testing without the CCRT filter is similar for the CARB specification diesel and GTL fuels and is a very small portion of the total $\mathrm{NO}_{x}$ emission. A substantial increase of almost $50 \%$ of the $\mathrm{NO}_{\mathrm{x}}$ emission in the calculated $\mathrm{NO}_{2}$ emissions is observed with the CCRT filter.

The increase in calculated $\mathrm{NO}_{2}$ with the CCRT filter was expected. These types of emission control devices continuously oxidize $\mathrm{NO}$ to $\mathrm{NO}_{2}$, which reduces the exhaust temperature needed to regenerate PM collected on the filter. With the very low average exhaust temperatures of this fleet, a highly active emission 
control device was selected, which is very active for $\mathrm{NO}_{2}$ production.

Figure 14. $\mathrm{NO}_{\mathrm{x}}$ and Calculated $\mathrm{NO}_{2}$ emissions for the CSHVR cycle.

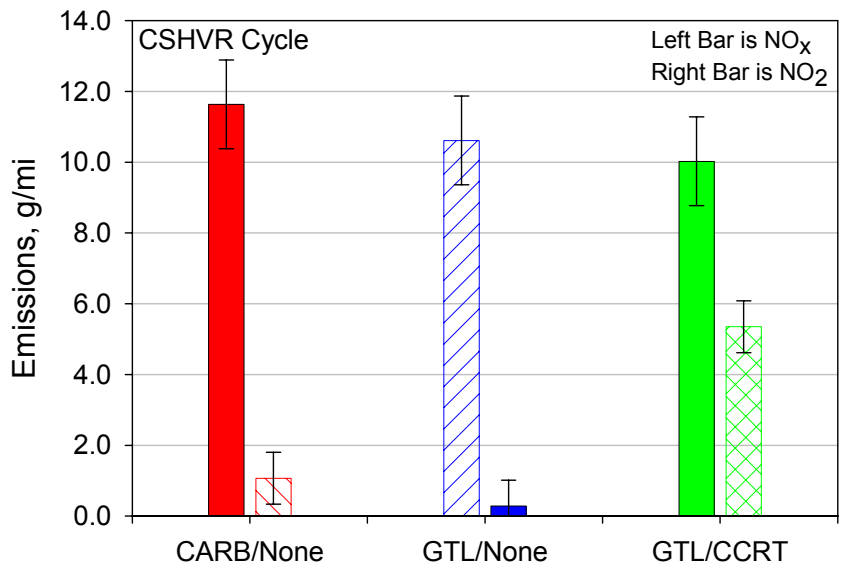

NYCB Cycle - Similar trends in the calculated $\mathrm{NO}_{2}$ emissions are observed in the NYCB cycle (Figure 15). The calculated $\mathrm{NO}_{2}$ comprises a very small portion of the total $\mathrm{NO}_{\mathrm{x}}$ emission for the GTL fuel and CARB specification diesel fuel. The presence of the CCRT filter substantially increases the calculated $\mathrm{NO}_{2}$ emission to roughly $50 \%$ of the total $\mathrm{NO}_{x}$ emission.

Figure 15. $\mathrm{NO}_{\mathrm{x}}$ and Calculated $\mathrm{NO}_{2}$ emissions for the NYCB cycle.

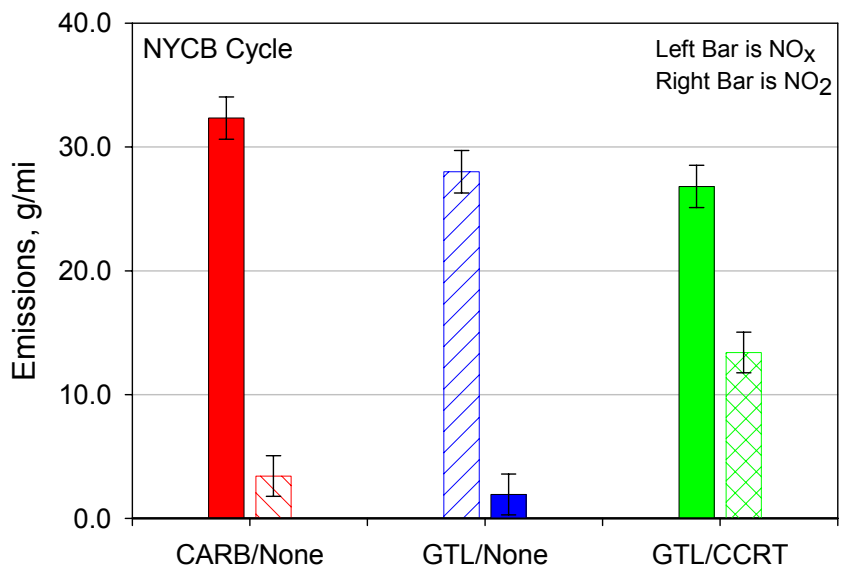

\section{FUEL ECONOMY}

CSHVR Cycle - The fuel economy is calculated from the $\mathrm{CO}_{2}$ emission and reported in miles per gallon (mpg). As shown in Figure 16 (CSHVR Cycle), there is very little difference between the fuels, with or without the emission control devices. The error bars on the following figures are one confidence interval, using the methods previously described and in Appendix A-3.

NYCB Cycle - Figure 17 presents the fuel economy for the vehicles over the NYCB cycle. As with the CSHVR cycle, the measured fuel economy does not change with GTL fuel, with and without the CCRT, compared to the CARB specification diesel.

Figure 16. Measured fuel economy over the CSHVR cycle.

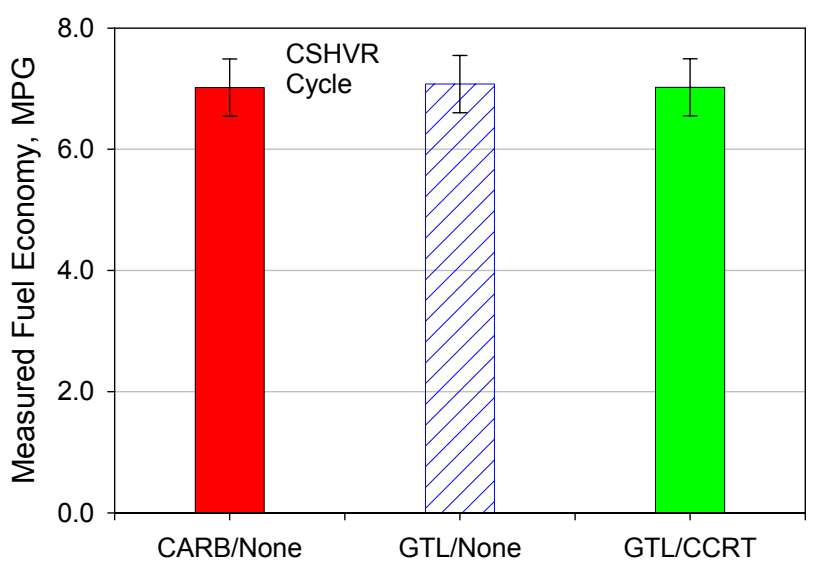

Figure 17. Measured fuel economy over the NYCB cycle.

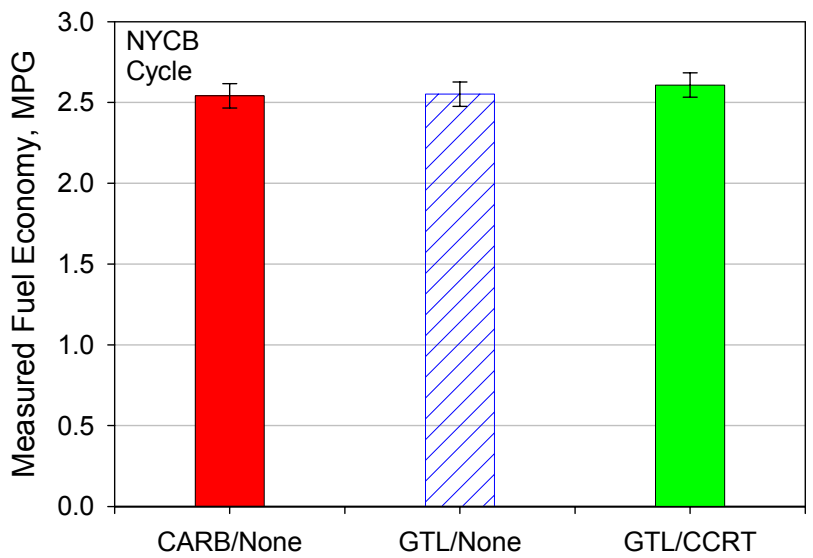

\section{STATISTICAL ANALYSIS OF EMISSION RESULTS}

A rigorous statistical analysis of the emission results was performed to determine the significance of the emission reductions observed with the GTL fuel with and without the CCRT filter compared to the CARB specification diesel fuel. A detailed analysis of the statistical method is in Appendix A-3.

CSHVR Cycle - The statistical analysis shows that although there is a $\mathrm{NO}_{x}$ reduction of almost $9 \%$ with the GTL fuel (no filter), this difference is not statistically significant at the $95 \%$ confidence level. The CO and PM emission reductions are also not significant at the $95 \%$ confidence level, although the $\mathrm{HC}$ emission reduction is significant. There was no impact on the fuel economy with the GTL fuel and/or the CCRT filter compared to the CARB specification diesel fuel. 
As expected, the CCRT filter and the GTL fuel caused significant reductions in the $\mathrm{HC}, \mathrm{CO}$, and $\mathrm{PM}$ emissions. The small additional $\mathrm{NO}_{x}$ reduction observed with the filter was not significant, compared either to the CARB specification diesel fuel or the GTL fuel without the filter.

The calculated $\mathrm{NO}_{2}$ emissions were increased significantly with the CCRT filter, compared to both the CARB specification diesel and the GTL fuel without the filter. This result was expected. Calculated $\mathrm{NO}_{2}$ emissions for the CARB specification diesel fuel, no filter, and the GTL fuel, no filter, were not calculated. The dual- $\mathrm{NO}_{\mathrm{x}}$ analyzer technique employed in this work was not sufficiently robust to distinguish between the very low levels of $\mathrm{NO}_{2}$ emitted from vehicles without emission control devices.

Table 7 shows which emission reductions are significant based on this analysis. "Yes" indicates that the change between fuel and/or filter technology is significant at the $95 \%$ confidence level, while "No" indicates the change is not significant. "NA" means that no comparison was possible. The directional arrows indicate whether the second fuel/filter combination increased $(\uparrow)$, decreased $(\downarrow)$, or made no change $(\leftrightarrow)$ in the emissions.

Table 7. Statistical Significance of Emissions Changes from Yosemite Waters Vehicles over the CSHVR Cycle.

\begin{tabular}{|c|c|c|c|c|c|c|}
\hline Comparison & HC & CO & NO $_{\mathbf{x}}$ & NO $_{2}$ & PM & MPG \\
\hline $\begin{array}{c}\text { CARB/No Filter } \\
\text { vs. }\end{array}$ & $\begin{array}{c}\text { Yes } \\
\downarrow\end{array}$ & $\begin{array}{c}\text { No } \\
\downarrow\end{array}$ & $\begin{array}{c}\text { No } \\
\downarrow\end{array}$ & NA & $\begin{array}{c}\text { No } \\
\downarrow\end{array}$ & $\begin{array}{c}\text { No } \\
\leftrightarrow\end{array}$ \\
\hline $\begin{array}{c}\text { GTL/No Filter } \\
\text { CARB/No Filter } \\
\text { vs. }\end{array}$ & $\begin{array}{c}\text { Yes } \\
\downarrow\end{array}$ & $\begin{array}{c}\text { Yes } \\
\downarrow\end{array}$ & $\begin{array}{c}\text { No } \\
\downarrow\end{array}$ & $\begin{array}{c}\text { Yes } \\
\uparrow\end{array}$ & $\begin{array}{c}\text { Yes } \\
\downarrow\end{array}$ & $\begin{array}{c}\text { No } \\
\leftrightarrow\end{array}$ \\
GTL/CCRT Filter & & & & & & \\
\hline $\begin{array}{c}\text { GTL/No Filter } \\
\text { vs. }\end{array}$ & $\begin{array}{c}\text { Yes } \\
\downarrow\end{array}$ & $\begin{array}{c}\text { Yes } \\
\downarrow\end{array}$ & $\begin{array}{c}\text { No } \\
\downarrow\end{array}$ & $\begin{array}{c}\text { Yes } \\
\uparrow\end{array}$ & $\begin{array}{c}\text { Yes } \\
\downarrow\end{array}$ & No \\
GTL/CCRT Filter & & & & & & \\
\hline
\end{tabular}

NYCB Cycle - The $\mathrm{NO}_{x}$ emission reduction that was observed with the GTL fuel, no filter, over the NYCB cycle was statistically significant $(13 \%)$. When comparing the emissions of the CARB specification diesel fuel and the GTL fuel, both without the filter, only the $\mathrm{HC}$ emission reduction was also significant (PM and $\mathrm{CO}$ emission reductions were not significant). The fuel economy over the test cycle did not change significantly with the GTL fuel compared to the CARB specification diesel fuel.

With the GTL fuel and the CCRT filter, all the emissions were reduced significantly compared to the CARB specification diesel fuel. The same results were observed when comparing the GTL fuel with and without the filter - all the emission reductions were significant at the $95 \%$ confidence level. Again, the fuel economy did not change significantly.

As with the CSHVR cycle, the calculated $\mathrm{NO}_{2}$ increased significantly with the CCRT filter, compared to testing without the filter. Statistical significance of the CARB/No filter and GTL/no filter was not tested due to the lack of robustness of the analysis technique for calculated $\mathrm{NO}_{2}$ emissions.

In the same format at Table 7, Table 8 shows the emission reductions over the NYCB cycle. Again, "NA" indicates that no comparison was made for these pollutants.

It should be noted that these results are only for this vehicle fleet, tested over the CSHVR and NYCB cycles.

Table 8. Statistical Significance of Emissions Changes from Yosemite Waters Vehicles over the CSHVR Cycle.

\begin{tabular}{|c|c|c|c|c|c|c|}
\hline Comparison & HC & CO & NO $_{\mathrm{x}}$ & NO $_{2}$ & PM & MPG \\
\hline $\begin{array}{c}\text { CARB/No Filter } \\
\text { vs. }\end{array}$ & $\begin{array}{c}\text { Yes } \\
\text { No }\end{array}$ & $\begin{array}{c}\text { No } \\
\text { Yes }\end{array}$ & NA & No & No \\
GTL/No Filter & $\downarrow$ & & & $\leftrightarrow$ \\
\hline $\begin{array}{c}\text { CARB/No Filter } \\
\text { vs. }\end{array}$ & $\begin{array}{c}\text { Yes } \\
\downarrow\end{array}$ & $\begin{array}{c}\text { Yes } \\
\downarrow\end{array}$ & $\begin{array}{c}\text { Yes } \\
\text { GTL/CCRT Filter }\end{array}$ & $\begin{array}{c}\text { Yes } \\
\text { Yes }\end{array}$ & $\begin{array}{c}\text { No } \\
\downarrow\end{array}$ & $\leftrightarrow$ \\
\hline $\begin{array}{c}\text { GTL/No Filter } \\
\text { vs. }\end{array}$ & $\begin{array}{c}\text { Yes } \\
\text { Yes }\end{array}$ & $\begin{array}{c}\text { Yes } \\
\downarrow\end{array}$ & $\begin{array}{c}\text { Yes } \\
\text { GTL/CCRT Filter }\end{array}$ & $\downarrow$ & $\begin{array}{c}\text { Yes } \\
\downarrow\end{array}$ & No \\
& & & $\uparrow$ & & $\leftrightarrow$ \\
\hline
\end{tabular}

\section{CONCLUSIONS}

Six 2001 International Class 6 trucks were selected for an operability and emissions study. Three vehicles were "baseline" vehicles, tested with CARB specification diesel fuel and no emission control devices. Three vehicles were operated on GTL fuel and retrofit with Johnson Matthey CCRT filters.

Prior to introduction into the fleet, the GTL fuel used in this study was subjected to extensive bench scale fuel property testing. The GTL fuel met or exceeded the ASTM D975 property specifications for low-sulfur diesel fuel.

Bench elastomer compatibility results showed that the fuels affected the elastomers equally. The results from the testing did not indicate potential problems when changing from CARB specification diesel fuel to GTL fuel. The change from CARB specification diesel fuel to the GTL fuel in the test vehicles was an overnight switch, with no vehicle preparation. No reports of elastomer compatibility issues (leaks, more frequent hose replacement, etc.) have been raised since the fuel change.

Once the vehicles were operating on GTL fuel, they were retrofit with Johnson Matthey CCRT filters. The vehicles were then put back into normal fleet operation. Data from on-board dataloggers show stable filter operation over the study period.

Chassis dynamometer emission testing was used to quantify the emission reductions with the GTL fuel and the CCRT filters. The GTL fueled vehicles were tested with and without the CCRT filters. Results show that: 
- The GTL fuel (no filter) reduced regulated emissions over the CSHVR and NYCB cycles, compared to CARB specification diesel fuel. Emission reductions over the CSHVR cycle were $58 \%$ for $\mathrm{HC}, 10 \%$ for $\mathrm{CO}, 8 \%$ for $\mathrm{NO}_{\mathrm{x}}$, and $33 \%$ for PM. Only the $\mathrm{HC}$ emissions reductions were significant at the $95 \%$ confidence level.

Emission reductions over the NYCB cycle were $69 \%$ for $\mathrm{HC}, 13 \%$ for $\mathrm{NO}_{\mathrm{x}}$, and $23 \%$ for $\mathrm{PM}$. A slight $\mathrm{CO}$ increase was noted $(0.8 \%)$. The $\mathrm{NO}_{\mathrm{x}}$ and $\mathrm{HC}$ emissions reductions were statistically significant.

The fuel economy did not change significantly over either test cycle, with any of the changes in fuel and/or emission control technologies.

- By combining the GTL fuel with the CCRT filter, even larger emission reductions were observed over both test cycles.

Emission reductions were over $99 \%$ for $\mathrm{HC}, \mathrm{CO}$, and $\mathrm{PM}$, with a $\mathrm{NO}_{\mathrm{x}}$ reduction of $14 \%$ for the CSHVR cycle. Significant emission reductions were observed for the $\mathrm{HC}, \mathrm{CO}$, and PM.

Testing over the NYCB cycle with the CCRT filter resulted in reductions greater than $97 \%$ for $\mathrm{HC}, \mathrm{CO}$, and $\mathrm{PM}$. $\mathrm{NO}_{x}$ emissions were reduced were $17 \%$. At the $95 \%$ confidence level, reductions were statistically significant for $\mathrm{HC}$, $\mathrm{CO}, \mathrm{PM}$, and $\mathrm{NO}_{\mathrm{x}}$.

As expected, the CCRT filter increased the calculated $\mathrm{NO}_{2}$ emissions from very low to almost $50 \%$ of the total $\mathrm{NO}_{x}$ emission, regardless of test cycle. The increase in calculated $\mathrm{NO}_{2}$ emissions was statistically significant for both the CSHVR and NYCB cycles.

The Yosemite Waters vehicles operated on GTL fuel with the CCRT filters through July 2004, accumulating between 10,000 and 24,000 miles. The fleet has not reported any problems with the change from CARB specification diesel to GTL fuel and the CCRT filters. To quantify the fleet experience, a thorough analysis of the maintenance records will be performed and reported in a future publication.

\section{ACKNOWLEDGMENT}

The authors would like to thank the Department of Energy's Office of Energy Efficiency and Renewable Energy, FreedomCAR and Vehicle Technologies Program, Fuels Technology Subprogram.

\section{REFERENCES}

1. "Fischer-Tropsch Technology", Howard, Weil, Labouisse, Friedrichs, December 18, 1998.
2. Alleman, T.L., McCormick, R.L., "Fischer-Tropsch Diesel Fuel - Properties and Exhaust Emissions: A Literature Review", SAE Technical Paper 2003-010763, 2003.

3. M. van der Burgt, J. van Klinken and T. Sie, "The Shell Middle Distillate Synthesis process", SIPC Selected Paper, November 1989; Updated from a paper given at 5th Synfuels Worldwide Symposium, Washington, DC, November 1985.

4. Advanced Fuels Properties Database, www.nrel.gov/vehiclesandfuels/fuels database.html.

5. Matheaus, A.C., Neely, G.D., Ryan III, T.W., Sobotowski, R.A., Wall, J.C., Hobbs, C.H., Passavant, G.,W., Bond, T.J., "EPA HDEWG Program-Engine Tests Results", SAE Technical Paper 2000-01-1858, 2000.

6. Ryan III, T.W., Buckingham, J., Dodge, L.G., Olikara, C., "The Effects of Fuel Properties on Emissions from a 2.5gm NOx Heavy-Duty Diesel Engine", SAE Technical Paper 982491, 1998.

7. Lee, R., Pedley, J., Hobbs, C., "Fuel Quality Impact on Heavy Duty Diesel Emissions: A Literature Review", SAE Technical Paper 982649, 1998.

8. Stavinoha, L.L., Alfaro, E.S., Dobbs Jr., H.H., Villahermosa, L.A., Heywood, J.B., "Alternative Fuels: Gas to Liquids as Potential $21^{\text {st }}$ Century Truck Fuels", SAE Paper Number 2000-01-3422, 2000.

9. Morgan, P.M., Viljoen, C.L., Roets, P.N., Schaberg, P.W., Myburgh, I.S., Botha, J.J., Dancuart, L.P., "Some Comparative Chemical, Physical and Compatibility Properties of Sasol Slurry Phase Distillate Diesel Fuel", SAE Technical Paper 982488, 1998.

10. Norton, P., Vertin, K., Clark, N.N., Lyons, D.W., Gautam, M., Goguen, S., Eberhardt, J., "Emissions from Buses with DDC 6V92 Engines Using Synthetic Diesel Fuel", SAE Technical Paper 1999-01-1512, 1999.

11. Sirman, M.B., Owens, E.C., Whitney, K.A., "Emissions Comparison of Alternative Fuels in an Advanced Automotive Diesel Engine", SAE Technical Paper 2000-01-2048, 2000.

12. Owen, K., Coley, T., Automotive Fuels Reference Book, $2^{\text {nd }}$ Edition, Society of Automotive Engineers, Warrendale, PA, 1995.

13. Ullman's Encyclopedia of Industrial Chemistry, Automotive Fuels - Fuel Components, Section 4.2, Wiley-VCH Verlag $\mathrm{GmbH}$, Weinheim, Germany, 2001.

14. Signer, M., Heinze, P., Mercogliano, R., Stein, H.J., "European Programme on Emissions, Fuels and Engine Technology (EPEFE) - Heavy Duty Diesel Study", SAE Technical Paper 961074, 1996.

15. Norton, P., Vertin, K., Bailey, B., Clark, N.N., Lyons, D.W., Goguen, S., Eberhardt, J., "Emissions from Trucks using Fischer-Tropsch Diesel Fuel", SAE Technical Paper No. 982526, 1998.

16. Report of the Diesel Fuel Task Force, February 18, 1994. 
17. Maxson, T., Logan, B., O'Brien, S., "Performance in Diesel and Biodiesels of Fluorosilicone Rubber Materials use for Automotive Quick Connector Fuel Line ORings and Other Sealing Applications", SAE Technical Paper 2001-01-1124, 2001.

18. Wang, W., Gautam, M., Sun, X., Bata, R., Clark, N., Palmer, M., and Lyons, D., "Emissions Comparisons of Twenty-Six Heavy Duty Vehicles Operated on Conventional and Alternative Fuels," SAE Technical Paper 932952, 1993.

19. Clark, N., Gautam, M., Bata, R., and Lyons, D., “ Design and Operation of a New Transportable Laboratory for Emissions Testing of Heavy-Duty Trucks and Buses," Int. Journal of Vehicle Design: Heavy Vehicle Systems, Vol. 2 Nos. 3/4, pp. 285299, 1995.

20. Wang, W., Bata, R., Lyons, D., Clark, N., Palmer, M., Gautam, M., Howell, A., Rapp, B., "Transient Response in a Dynamometer Power Absorption System," SAE Technical Paper 920252, 1992.

21. Schaberg, P.W., Myburgh, I.S., Botha, J.J., Khalek, I.A., "Comparative Emissions Performance of Sasol Fischer-Tropsch Diesel Fuel in Current and Older Technology Heavy-Duty Engines", SAE Technical Paper 2000-01-1912, 2000.

22. Allansson, R., Blakeman, P.G., Cooper, B.J., Hess, H., Silcock, P.J., Walker, A.P., "Optimising the Low Temperature Performance and Regeneration Efficiency of the Continuously Regenerating Diesel Particulate Filter (CR-DPF) System", SAE Technical Paper 2002-01-0428, 2002.

23. LeTavec, C., Uihlein, J., Vertin, K., Chatterjee, S., Wayne, S., Clark, N., Gautam, M., Thompson, G., Lyons, D., Hallstrom, K., Chandler, K., Coburn, T., "Year-Long Evaluation of Trucks and Buses Equipped with Passive Diesel Particulate Filters", SAE Technical Paper 2002-01-0433, 2002.

\section{CONTACT}

Teresa Alleman, National Renewable Energy Laboratory, 303.275.4514 or Adewale Oshinuga, South Coast Air Quality Management District, 909.396.2599.

\section{ABBREVIATIONS}

ASTM: American Society of Testing and Materials

CARB: California Air Resources Board

CCRT: Catalyzed Continuously Regenerating Technology

CDPF: Catalyzed diesel particulate filter

CO: Carbon monoxide

$\mathrm{CO}_{2}$ : Carbon dioxide

CSHVR: City Suburban Heavy Vehicle Route

${ }^{\circ} \mathrm{C}$ : Degree Centigrade

g/mi: Grams per mile

g/mL: Grams per mililiter

GTL: Gas-to-liquid

HC: Hydrocarbons

HNBR: Hydrogenated nitrile buna rubber
HPC: Heavy Paraffin Conversion

HPS: Heavy Paraffin Synthesis

mpg: Miles per gallon

$\mathbf{N}_{\mathbf{2}}$ : Atomic nitrogen

$\mathrm{NO}_{2}$ : Nitrogen dioxide

$\mathrm{NO}_{\mathbf{x}}$ : Oxides of nitrogen

NYCB: New York City Bus

PM: Particulate matter

SMDS: Shell Middle Distillate Synthesis 


\section{APPENDIX A-1.}

Elastomer Compatibility Results.

\begin{tabular}{|c|c|c|c|c|c|c|c|c|}
\hline $\begin{array}{c}\text { Test Parameter } \\
\end{array}$ & \multicolumn{2}{|c|}{ Elastomer $\mathbf{A}$} & \multicolumn{2}{|c|}{ Elastomer B } & \multicolumn{2}{|c|}{ Elastomer C1 } & \multicolumn{2}{|c|}{ Elastomer C2 } \\
\hline \multicolumn{9}{|c|}{$\begin{array}{l}\text { CARB Specification Diesel } 60^{\circ} \mathrm{C} \\
\text { for } 1,000 \text { Hours }\end{array}$} \\
\hline $\begin{array}{c}\text { Hardness Change } \\
\text { Seal } 1 \\
\text { Seal } 2 \\
\text { Seal } 3 \\
\end{array}$ & $\begin{array}{l}+ \\
+ \\
+\end{array}$ & & $\begin{array}{c}+ \\
0 \\
+\end{array}$ & & - & & $\begin{array}{l}+ \\
+ \\
+\end{array}$ & \\
\hline $\begin{array}{c}\text { \%olume Change } \\
\text { Seal } 1 \\
\text { Seal } 2 \\
\text { Seal } 3\end{array}$ & $\begin{array}{l}+2 \\
+2 \\
+2\end{array}$ & & $\begin{array}{l}+2 \\
+2 \\
+2\end{array}$ & & $\begin{array}{l}+2 \\
+2 \\
+2\end{array}$ & & \multicolumn{2}{|c|}{$\begin{array}{l}+14.93 \\
+14.45\end{array}$} \\
\hline Reversion & \multicolumn{2}{|c|}{$\frac{+2.56}{20 \text { reyersion }}$} & No rev & sion & No rev & sion & No rev & rsion \\
\hline Bend Test & $\mathrm{Pa}$ & & $\mathrm{Pa}$ & & $\mathrm{Pa}$ & & $\mathrm{Pa}$ & \\
\hline Radial Thickness & Before & After & Before & After & Before & After & Before & After \\
\hline Seal 1 & 3.13 & 3.17 & 3.44 & 3.51 & 3.04 & 3.17 & 2.64 & 2.50 \\
\hline Seal 2 & 3.12 & 3.16 & 3.45 & 3.51 & 3.06 & 3.17 & 2.66 & 2.51 \\
\hline Seal 3 & 3.11 & 3.16 & 3.44 & 3.49 & 3.05 & 3.17 & 2.64 & 2.50 \\
\hline Sediment Observation & None O & served & None Ol & erved & None O & erved & None O & served \\
\hline GTL Fuel $60^{\circ} \mathrm{C}$ for $1,000 \mathrm{Hc}$ & & & & & & & & \\
\hline $\begin{array}{c}\text { Hardness Change } \\
\text { Seal } 1 \\
\text { Seal } 2 \\
\text { Seal } 3\end{array}$ & $\begin{array}{l}+ \\
+ \\
+\end{array}$ & & $\begin{array}{l}+ \\
+ \\
+\end{array}$ & & - & & $\begin{array}{l}+ \\
+ \\
+\end{array}$ & \\
\hline $\begin{array}{c}\text { Volume Change } \\
\text { Seal } 1 \\
\text { Seal } 2 \\
\text { Seal } 3\end{array}$ & $\begin{array}{l}+1 \\
+2 \\
+2\end{array}$ & & $\begin{array}{l}+1 \\
+1 \\
+1\end{array}$ & & $\begin{array}{l}+1 \\
+1 \\
+2\end{array}$ & & $\begin{array}{l}-0 \\
-0 \\
+0\end{array}$ & \\
\hline Reversion & No rev & rsion & No rev & sion & No rev & sion & No rev & rsion \\
\hline Bend Test & $\mathrm{Pa}$ & & $\mathrm{Pa}$ & & $\mathrm{Pa}$ & & & \\
\hline Radial Thickness & Before & After & Before & After & Before & After & Before & After \\
\hline Seal 1 & 3.12 & 3.16 & 3.46 & 3.46 & 3.05 & 3.17 & 2.63 & 2.62 \\
\hline Seal 2 & 3.13 & 3.16 & 3.45 & 3.46 & 3.06 & 3.17 & 2.63 & 2.63 \\
\hline Seal 3 & 3.13 & 3.17 & 3.45 & 3.46 & 3.05 & 3.17 & 2.64 & 2.63 \\
\hline Sediment Observation & None ol & served & None of & erved & None ol & erved & None o & erved \\
\hline $\begin{array}{c}\text { CARB Specification Diesel } 60^{\circ} \mathrm{C} \\
\text { Hours } \rightarrow \\
\text { GTL Fuel } 60^{\circ} \mathrm{C} \text { for } 500 \mathrm{Ho}\end{array}$ & & & & & & & & \\
\hline $\begin{array}{c}\text { Hardness Change } \\
\text { Seal } 1 \\
\text { Seal } 2 \\
\text { Seal } 3\end{array}$ & c & & c & & c & & & \\
\hline $\begin{array}{c}\text { \% Volume Change } \\
\text { Seal } 1 \\
\text { Seal } 2 \\
\text { Seal } 3\end{array}$ & $\begin{array}{l}+1 \\
+1 \\
+1\end{array}$ & & $\begin{array}{l}+0 \\
+0 \\
+0\end{array}$ & & $\begin{array}{l}+0 \\
+0 \\
+0\end{array}$ & & & \\
\hline Reversion & No rev & rsion & No rev & sion & No rev & sion & No re & rsion \\
\hline Bend Test & $\mathrm{Pa}$ & & $\mathrm{Pa}$ & & $\mathrm{Pa}$ & & & \\
\hline Radial Thickness & Before & After & Before & After & Before & After & Before & After \\
\hline Seal 1 & 3.13 & 3.23 & 3.44 & 3.45 & 3.05 & 3.11 & 2.66 & 2.54 \\
\hline Seal 2 & 3.14 & 3.23 & 3.45 & 3.46 & 3.06 & 3.12 & 2.65 & 2.52 \\
\hline Seal 3 & 3.12 & 3.22 & 3.44 & 3.45 & 3.06 & 3.11 & 2.66 & 2.53 \\
\hline Sediment Observation & None ol & served & None ol & erved & None ol & erved & None 0 & erved \\
\hline
\end{tabular}


APPENDIX A-1.

Elastomer Compatibility Results (con't).

\begin{tabular}{|c|c|c|c|c|c|c|c|}
\hline $\begin{array}{c}\text { Elastomer } \\
\text { Type }\end{array}$ & Condition & $\begin{array}{c}\text { Inside } \\
\text { Diameter }\end{array}$ & $\begin{array}{c}\text { O-ring } \\
\text { Thickness }\end{array}$ & $\begin{array}{c}\text { Inside } \\
\text { Circumference }\end{array}$ & $\begin{array}{c}\text { Extension } \\
\text { at Break }\end{array}$ & Elongation & $\begin{array}{c}\text { Average } \\
\text { Elongation }\end{array}$ \\
\hline & & (in) & (in) & (in) & (in) & (\%) & (\%) \\
\hline A & Control & 1.23 & 0.123 & 3.8622 & 2.611 & 75.9 & 74.4 \\
\hline A & Control & 1.23 & 0.123 & 3.8622 & 2.72 & 81.5 & \\
\hline $\bar{A}$ & Control & 1.23 & 0.123 & 3.8622 & 2.417 & 65.8 & \\
\hline A & \multirow{3}{*}{$\begin{array}{l}\text { GTL Fuel } \\
1,000 \text { Hrs }\end{array}$} & 1.23 & 0.123 & 3.8622 & 2.55 & 72.7 & 81.3 \\
\hline A & & 1.23 & 0.123 & 3.8622 & 2.93 & 92.4 & \\
\hline A & & 1.23 & 0.123 & 3.8622 & 2.666 & 78.7 & \\
\hline A & \multirow{3}{*}{$\begin{array}{l}\text { CARB Specification } \\
\text { Diesel } 500 \mathrm{Hrs} \rightarrow \\
\text { GTL Fuel } 500 \mathrm{Hrs}\end{array}$} & 1.23 & 0.123 & 3.8622 & 2.611 & 75.9 & 82.3 \\
\hline A & & 1.23 & 0.123 & 3.8622 & 2.906 & 91.1 & \\
\hline A & & 1.23 & 0.123 & 3.8622 & 2.69 & 79.9 & \\
\hline A & \multirow{3}{*}{$\begin{array}{l}\text { CARB Specification } \\
\text { Diesel 1,000 Hrs }\end{array}$} & 1.23 & 0.123 & 3.8622 & 2.77 & 84.1 & 81.3 \\
\hline A & & 1.23 & 0.123 & 3.8622 & 2.837 & 87.6 & \\
\hline $\mathrm{A}$ & & 1.23 & 0.123 & 3.8622 & 2.542 & 72.3 & \\
\hline $\mathrm{B}$ & Control & 0.91 & 0.139 & 2.8574 & 2.417 & 124.1 & 130.6 \\
\hline$B$ & Control & 0.91 & 0.139 & 2.8574 & 2.717 & 145.1 & \\
\hline B & Control & 0.91 & 0.139 & 2.8574 & 2.393 & 122.4 & \\
\hline B & \multirow{3}{*}{$\begin{array}{l}\text { GTL Fuel } \\
1,000 \text { Hrs }\end{array}$} & 0.91 & 0.139 & 2.8574 & 2.82 & 152.3 & 153.9 \\
\hline B & & 0.91 & 0.139 & 2.8574 & 2.852 & 154.6 & \\
\hline B & & 0.91 & 0.139 & 2.8574 & 2.857 & 154.9 & \\
\hline$B$ & \multirow{3}{*}{$\begin{array}{l}\text { CARB Specification } \\
\text { Diesel } 500 \mathrm{Hrs} \rightarrow \\
\text { GTL Fuel } 500 \mathrm{Hrs}\end{array}$} & 0.91 & 0.139 & 2.8574 & 2.723 & 145.5 & 143.6 \\
\hline$B$ & & 0.91 & 0.139 & 2.8574 & 2.84 & 153.7 & \\
\hline B & & 0.91 & 0.139 & 2.8574 & 2.524 & 131.6 & \\
\hline B & \multirow{3}{*}{$\begin{array}{l}\text { CARB Specification } \\
\text { Diesel } 1,000 \text { Hrs }\end{array}$} & 0.91 & 0.139 & 2.8574 & 2.933 & 160.2 & 152.7 \\
\hline B & & 0.91 & 0.139 & 2.8574 & 2.816 & 152.0 & \\
\hline$B$ & & 0.91 & 0.139 & 2.8574 & 2.726 & 145.7 & \\
\hline $\mathrm{C} 1$ & Control & 1.331 & 0.124 & 4.17934 & 3.88 & 123.2 & 110.6 \\
\hline C1 & Control & 1.331 & 0.124 & 4.17934 & 3.756 & 117.3 & \\
\hline C1 & Control & 1.331 & 0.124 & 4.17934 & 3.214 & 91.4 & \\
\hline C1 & \multirow{3}{*}{$\begin{array}{l}\text { GTL Fuel } \\
1,000 \mathrm{Hrs}\end{array}$} & 1.331 & 0.124 & 4.17934 & 3.587 & 109.2 & 108.2 \\
\hline C1 & & 1.331 & 0.124 & 4.17934 & 3.634 & 111.5 & \\
\hline C1 & & 1.331 & 0.124 & 4.17934 & 3.473 & 103.8 & \\
\hline C1 & \multirow{3}{*}{$\begin{array}{l}\text { CARB Specification } \\
\text { Diesel } 500 \mathrm{Hrs} \rightarrow \\
\text { GTL Fuel } 500 \mathrm{Hrs}\end{array}$} & 1.331 & 0.124 & 4.17934 & 3.939 & 126.1 & 117.5 \\
\hline C1 & & 1.331 & 0.124 & 4.17934 & 3.699 & 114.6 & \\
\hline C1 & & 1.331 & 0.124 & 4.17934 & 3.64 & 111.8 & \\
\hline C1 & \multirow{3}{*}{$\begin{array}{c}\text { CARB Specification } \\
\text { Diesel } 1,000 \text { Hrs }\end{array}$} & 1.331 & 0.124 & 4.17934 & 3.487 & 104.4 & 116.0 \\
\hline C1 & & 1.331 & 0.124 & 4.17934 & 3.99 & 128.5 & \\
\hline C1 & & 1.331 & 0.124 & 4.17934 & 3.71 & 115.1 & \\
\hline
\end{tabular}




\section{APPENDIX A-1.}

Elastomer Compatibility Results (con't).

\begin{tabular}{|c|c|c|c|c|c|c|c|}
\hline $\begin{array}{l}\text { Elastomer } \\
\text { Type }\end{array}$ & Condition & \begin{tabular}{|c} 
Inside \\
Diameter
\end{tabular} & $\begin{array}{c}\text { O-ring } \\
\text { Thickness }\end{array}$ & $\begin{array}{c}\text { Inside } \\
\text { Circumference }\end{array}$ & $\begin{array}{c}\text { Extension } \\
\text { at Break }\end{array}$ & Elongation & $\begin{array}{c}\text { Average } \\
\text { Elongation }\end{array}$ \\
\hline & & (in) & (in) & (in) & (in) & $(\%)$ & $(\%)$ \\
\hline $\mathrm{C} 2$ & Control & 1.35 & 0.103 & 4.239 & 3.824 & 117.5 & 143.3 \\
\hline $\mathrm{C} 2$ & Control & 1.35 & 0.103 & 4.239 & 4.666 & 157.2 & \\
\hline $\mathrm{C} 2$ & Control & 1.35 & 0.103 & 4.239 & 4.626 & 155.3 & \\
\hline $\mathrm{C} 2$ & \multirow{3}{*}{$\begin{array}{l}\text { GTL Fuel } \\
1,000 \text { Hrs }\end{array}$} & 1.35 & 0.103 & 4.239 & 4.403 & 144.8 & 147.8 \\
\hline $\mathrm{C} 2$ & & 1.35 & 0.103 & 4.239 & 4.494 & 149.1 & \\
\hline $\mathrm{C} 2$ & & 1.35 & 0.103 & 4.239 & 4.507 & 149.7 & \\
\hline $\mathrm{C} 2$ & \multirow{3}{*}{$\begin{array}{l}\text { CARB Specification } \\
500 \mathrm{Hrs} \rightarrow \\
\text { GTL Fuel } 500 \text { Hrs }\end{array}$} & 1.35 & 0.103 & 4.239 & 4.073 & 129.2 & 115.6 \\
\hline $\mathrm{C} 2$ & & 1.35 & 0.103 & 4.239 & 3.757 & 114.3 & \\
\hline $\mathrm{C} 2$ & & 1.35 & 0.103 & 4.239 & 3.523 & 103.3 & \\
\hline $\mathrm{C} 2$ & \multirow{3}{*}{$\begin{array}{l}\text { CARB Specification } \\
\text { Diesel } 1,000 \mathrm{Hrs}\end{array}$} & 1.35 & 0.103 & 4.239 & 5.657 & 203.9 & 170.1 \\
\hline $\mathrm{C} 2$ & & 1.35 & 0.103 & 4.239 & 4.506 & 149.6 & \\
\hline $\mathrm{C} 2$ & & 1.35 & 0.103 & 4.239 & 4.656 & 156.7 & \\
\hline
\end{tabular}




\section{APPENDIX A-2.}

Detailed Chassis Emissions Results from Yosemite Waters Testing, Ordered by Run Number.

\begin{tabular}{|c|c|c|c|c|c|c|c|c|c|c|c|c|}
\hline Run & Vehicle & Fuel & $\begin{array}{c}\text { Emission } \\
\text { Control }\end{array}$ & Cycle & CO & $\mathrm{NO}_{\mathrm{x}} \mathrm{1}$ & $\mathrm{NO}_{\mathrm{x}} 2$ & NO & $\mathrm{HC}$ & PM & $\mathrm{CO}_{2}$ & MPG \\
\hline 2792-1 & 201 & CARB & None & NYCB & 5.09 & 31.9 & 31.6 & & 1.56 & 0.61 & 3890 & 2.57 \\
\hline 2792-2 & 201 & CARB & None & NYCB & 5.52 & 32.3 & & 28.3 & 1.37 & 0.55 & 3856 & 2.69 \\
\hline \multirow[t]{2}{*}{ 2792-3 } & 201 & CARB & None & NYCB & 6.18 & 30.7 & & 27.5 & 1.54 & 0.56 & 3940 & 2.54 \\
\hline & & & & Average & 5.60 & 31.6 & & 27.9 & 1.49 & 0.57 & 3895 & 2.60 \\
\hline 2793-1 & 201 & CARB & None & CSHVR & 2.00 & 11.5 & 11.8 & & 0.42 & 0.19 & 1461 & 6.86 \\
\hline 2793-2 & 201 & CARB & None & CSHVR & 1.91 & 11.6 & & 10.3 & 0.48 & 0.19 & 1455 & 6.88 \\
\hline \multirow[t]{2}{*}{ 2793-3 } & 201 & CARB & None & CSHVR & 1.89 & 11.1 & & 10.0 & 0.45 & 0.17 & 1414 & 7.09 \\
\hline & & & & Average & 1.93 & 11.4 & & 10.2 & 0.45 & 0.18 & 1443 & 6.94 \\
\hline $2797-1$ & 202 & CARB & None & NYCB & 6.26 & 33.3 & 33.9 & & 1.48 & 0.67 & 3932 & 2.55 \\
\hline $2797-2$ & 202 & CARB & None & YCB & 6.92 & 34.5 & & 31.3 & 1.34 & 0.63 & 4073 & 2.46 \\
\hline \multirow[t]{2}{*}{$2797-3$} & 202 & CARB & None & YCB & 9.35 & 32.3 & & 28.4 & 1.33 & 0.80 & 3857 & 2.59 \\
\hline & & & & Average & 7.51 & 33.4 & & 29.9 & 1.38 & 0.70 & 3954 & 2.53 \\
\hline 2798-1 & 202 & CARB & None & CSHVR & 1.90 & 11.9 & 12.3 & & 0.45 & 0.17 & 1417 & 7.07 \\
\hline 2798-2 & 202 & CARB & None & CSHVR & 2.15 & 11.6 & & 10.5 & 0.52 & 0.17 & 1396 & 7.17 \\
\hline \multirow[t]{2}{*}{ 2798-3 } & 202 & CARB & None & CSHVR & 2.80 & 11.6 & & 10.7 & 0.47 & 0.16 & 1403 & 7.14 \\
\hline & & & & Average & 2.28 & 11.7 & & 10.6 & 0.48 & 0.17 & 1405 & 7.13 \\
\hline 2802-1 & 203 & CARB & None & NYCB & 4.68 & 32.1 & 32.2 & & 1.56 & 0.80 & 3988 & 2.51 \\
\hline 2802-2 & 203 & CARB & None & NYCB & 5.41 & 31.9 & & 28.6 & 1.87 & 0.65 & 3997 & 2.50 \\
\hline \multirow[t]{2}{*}{ 2802-3 } & 203 & CARB & None & YCB & 6.25 & 32.0 & & 29.1 & 1.84 & 0.65 & 4072 & 2.46 \\
\hline & & & & Average & 5.45 & 32.0 & & 28.9 & 1.76 & 0.70 & 4019 & 2.49 \\
\hline 2805-1 & 203 & CARB & None & CSHVR & 1.39 & 12.1 & 12.1 & & 0.43 & 0.16 & 1476 & 6.79 \\
\hline 2805-2 & 203 & CARB & None & CSHVR & 1.36 & 11.7 & & 10.6 & 0.47 & 0.15 & 1422 & 7.05 \\
\hline \multirow[t]{2}{*}{ 2805-3 } & 203 & CARB & None & CSHVR & 1.53 & 11.6 & & 10.7 & 0.43 & 0.15 & 1408 & 7.12 \\
\hline & & & & Average & 1.43 & 11.8 & & 10.7 & 0.44 & 0.15 & 1435 & 6.99 \\
\hline 2809-1 & 205 & GTL & CCRT & NYCB & 0.00 & 25.9 & 25.6 & & 0.00 & 0.05 & 3609 & 2.56 \\
\hline 2809-2 & 205 & GTL & CCRT & NYCB & 0.00 & 25.7 & & 13.2 & 0.00 & 0.02 & 3595 & 2.57 \\
\hline \multirow[t]{2}{*}{ 2809-3 } & 205 & GTL & CCRT & NYCB & 0.00 & 24.8 & & 13.7 & 0.00 & 0.02 & 3520 & 2.62 \\
\hline & & & & Average & 0.00 & 25.5 & & 13.5 & 0.00 & 0.03 & 3575 & 2.58 \\
\hline 2813-1 & 205 & GTL & CCRT & CSHVR & 0.00 & 9.1 & 9.1 & & 0.00 & 0.00 & 1268 & 7.29 \\
\hline 2813-2 & 205 & GTL & CCRT & CSHVR & 0.00 & 8.7 & & 4.2 & 0.00 & 0.00 & 1224 & 7.55 \\
\hline \multirow[t]{2}{*}{ 2813-3 } & 205 & GTL & CCRT & CSHVR & 0.00 & 8.7 & & 4.3 & 0.00 & 0.00 & 1220 & 7.57 \\
\hline & & & & Average & 0.00 & 8.8 & & 4.3 & 0.00 & 0.00 & 1237 & 7.47 \\
\hline 2819-1 & 205 & GTL & None & NYCB & 5.56 & 26.6 & 26.5 & & 0.28 & 0.37 & 3479 & 2.65 \\
\hline 2819-2 & 205 & GTL & None & NYCB & 4.91 & 26.3 & & 23.9 & 0.36 & 0.36 & 3494 & 2.64 \\
\hline \multirow[t]{2}{*}{ 2819-3 } & 205 & GTL & None & NYCB & 5.33 & 26.8 & & 24.9 & 0.42 & 0.30 & 3588 & 2.57 \\
\hline & & & & Average & 5.27 & 26.6 & & 24.4 & 0.35 & 0.34 & 3187 & 2.62 \\
\hline $2820-1$ & 205 & GTL & None & CSHVR & 1.26 & 9.5 & 9.7 & & 0.16 & 0.10 & 1248 & 7.38 \\
\hline $2820-2$ & 205 & GTL & None & CSHVR & 1.27 & 9.2 & & 8.5 & 0.15 & 0.08 & 1208 & 7.63 \\
\hline \multirow[t]{2}{*}{$2820-3$} & 205 & GTL & None & CSHVR & 1.32 & 9.2 & & 8.6 & 0.14 & 0.09 & 1218 & 7.57 \\
\hline & & & & Average & 1.28 & 9.3 & & 8.6 & 0.15 & 0.09 & 1225 & 7.53 \\
\hline
\end{tabular}




\section{APPENDIX A-2.}

Detailed Chassis Emissions Results from Yosemite Waters Testing, Ordered by Run Number (con't).

\begin{tabular}{|c|c|c|c|c|c|c|c|c|c|c|c|c|}
\hline Run & Vehicle & Fuel & $\begin{array}{c}\text { Emission } \\
\text { Control }\end{array}$ & Cycle & co & $\mathrm{NO}_{\mathrm{x}} 1$ & $\mathrm{NO}_{\mathrm{x}} 2$ & NO & HC & PM & $\mathrm{CO}_{2}$ & MPG \\
\hline 2822-1 & 206 & GTL & CCRT & CSHVR & 0.00 & 10.6 & 10.5 & & 0.00 & 0.00 & 1409 & 6.56 \\
\hline $2822-2$ & 206 & GTL & CRT & CSHVR & 0.00 & 10.3 & & 4.5 & 0.00 & 0.00 & 1371 & 6.74 \\
\hline \multirow[t]{2}{*}{$2822-3$} & 206 & TL & CCRT & SHVR & 0.00 & 10.5 & & .4 & .00 & 0.00 & 1369 & 6.75 \\
\hline & & & & Average & 0.00 & 10.5 & & 4.5 & 0.00 & 0.00 & 1383 & 6.68 \\
\hline 2823-1 & 206 & STL & CRT & NYCB & 0.00 & 25.8 & & & 0.00 & 0.01 & 3388 & 2.73 \\
\hline 2823-2 & 206 & GTL & CCRT & NYCB & 0.00 & 27.8 & & 14.4 & 0.00 & 0.00 & 3593 & 2.57 \\
\hline \multirow[t]{2}{*}{ 2823-3 } & 206 & GTL & CCRT & YCB & 0.00 & 27.4 & & 15.2 & 0.00 & 0.06 & 3516 & 2.63 \\
\hline & & & & Average & 0.00 & 27.0 & & 14.8 & 0.00 & 0.02 & 3499 & 2.64 \\
\hline 2826-1 & 206 & TL & lone & NYCB & 4.58 & 27.8 & & & 0.33 & 0.48 & 3572 & 2.58 \\
\hline $2826-2$ & 206 & GTL & None & YCB & 5.59 & 29.0 & & 27.5 & 0.54 & 0.46 & 3701 & 2.49 \\
\hline \multirow[t]{2}{*}{ 2826-3 } & 206 & GTL & None & YCB & 4.89 & 29.8 & & 28.2 & 0.54 & 0.40 & 3856 & 2.39 \\
\hline & & & & Average & 5.02 & 28.9 & & 27.9 & 0.47 & 0.45 & 3710 & 2.49 \\
\hline 2828-1 & 206 & GTL & one & VR & 1.55 & 11.6 & & & 0.15 & 0.11 & 1369 & 6.73 \\
\hline 2828-2 & 206 & GTL & None & CSHVR & 1.39 & 11.6 & & 11.2 & 0.20 & 0.10 & 1375 & 6.70 \\
\hline \multirow[t]{2}{*}{ 2828-3 } & 206 & GTL & None & SHVR & 1.45 & 11.2 & & 10.9 & 0.21 & 0.09 & 1353 & 6.81 \\
\hline & & & & Average & 1.46 & 11.5 & & 11.1 & 0.19 & 0.10 & 1366 & 6.75 \\
\hline 2830-1 & 204 & GTL & CRT & CSHVR & 0.00 & 10.8 & & & 0.00 & 0.00 & 1364 & 6.77 \\
\hline 2830-2 & 204 & GTL & CCRT & CSHVR & 0.08 & 10.8 & & 4.9 & 0.00 & 0.00 & 1321 & 6.97 \\
\hline \multirow[t]{2}{*}{ 2830-3 } & 204 & GTL & CCRT & SHVR & 0.00 & 10.7 & & 5.3 & 0.00 & 0.00 & 1321 & 6.99 \\
\hline & & & & Average & 0.03 & 10.8 & & 5.1 & 0.00 & 0.00 & 1335 & 6.91 \\
\hline 2833-1 & 204 & GTL & CRT & CB & 0.00 & 28.2 & 27.0 & & 0.00 & 0.01 & 3229 & 2.62 \\
\hline 2833-2 & 204 & GTL & CCRT & YCB & 0.00 & 28.6 & & 12.7 & 0.00 & 0.01 & 3615 & 2.56 \\
\hline \multirow[t]{2}{*}{ 2833-3 } & 204 & GTL & CCRT & NYCB & 0.00 & 27.1 & & 11.8 & 0.00 & 0.00 & 3535 & 2.61 \\
\hline & & & & Average & 0.00 & 28.0 & & 12.3 & 0.00 & 0.01 & 3460 & 2.60 \\
\hline 2835-1 & 204 & GTL & None & YCB & 7.55 & 28.3 & 18.9 & & 0.55 & 0.92 & 3650 & 2.52 \\
\hline $2835-2$ & 204 & GTL & None & YCB & 8.76 & 29.4 & & 26.5 & 0.65 & 0.63 & 3617 & 2.54 \\
\hline \multirow[t]{2}{*}{ 2835-3 } & 204 & GTL & None & NYCB & 8.94 & 28.0 & & 26.7 & 0.63 & 0.61 & 3561 & 2.58 \\
\hline & & & & Average & 8.42 & 28.6 & & 26.6 & 0.61 & 0.72 & 3276 & 2.55 \\
\hline $2837-2$ & 204 & GTL & None & CSHVR & 2.33 & 11.1 & & 11.0 & 0.24 & 0.16 & 1341 & 6.86 \\
\hline $2837-3$ & 204 & GTL & None & CSHVR & 2.11 & 10.9 & & 11.3 & 0.24 & 0.15 & 1318 & 6.98 \\
\hline \multirow[t]{2}{*}{$2837-4$} & 204 & GTL & None & CSHVR & 2.45 & 11.2 & 11.2 & & 0.24 & 0.14 & 1312 & 7.01 \\
\hline & & & & Average & 2.30 & 11.1 & & 11.3 & 0.24 & 0.15 & 1324 & 6.95 \\
\hline
\end{tabular}




\section{APPENDIX A-3.}

Description of Statistical Technique Used to Analyze Emissions Results for Statistical Significance.

The statistical analysis of the emissions data is performed using a mixed-model analysis of variance (ANOVA) approach. The model accounts for the fixed effects of test fleet (CARB/none, GTL/none, and GTL/CCRT) and test cycle (CSHVR and NYCB) and the random effects of differences in vehicles, tests, and measurements. Specifically, the full model used for the analyses is

$Y_{i j k l r}=\mu+\alpha_{i}+\beta_{j}+\alpha \beta_{i j}+Y_{k(j)}+\delta_{(j)}+\varepsilon_{r(j k k l)}$,

where $Y_{i j k r}$ denotes the $r^{\text {th }}$ replicate measurement in the $i^{\text {th }}$ test run on the $k^{\text {th }}$ vehicle under cycle $j$ for fleet $i$. The terms $\alpha_{i}$ and $\beta_{j}$ denote the fixed effects of fleet and cycle, respectively, while the term $\alpha \beta_{i j}$ denotes the interaction of fleet and cycle. This term allows the effect of fleet to vary by cycle. The random effect $Y_{k(j)}$ accounts for vehicle-to-vehicle variability, while the random effect $\delta_{(0)}$ explains the test-to-test variability. The error term $\varepsilon_{r(j i k l)}$ represents the variability of the three replicate measurements made within a specific test run. The subscript $r(i j k l)$ refers to nesting of replicate numbers within unique test runs. It is assumed that the random effects are independent and distributed approximately by a normal (Gaussian) distribution with mean zero and standard deviations $\sigma_{\gamma j}, \sigma_{\delta j}$, and $\sigma_{\varepsilon j}$, respectively. The index $j$ indicates that the standard deviations of the effects $Y_{k(j)}, \delta_{(j)}$, and $\varepsilon_{r(i k k)}$ are estimated separately by cycle. This model was applied separately for each pollutant using the PROC MIXED procedure in the Statistical Analysis System (SAS®) software. Comparisons between fleet by cycle and between cycle by fleet were obtained using the DIFF=ALL option on the LSMEANS statement. Ninety-five percent (95\%) confidence intervals were calculated for the estimated means and differences. Satterthwaite's method was used to determine the degrees of freedom associated with the standard errors of the estimates.

The exceptions to the approach described above are as follows: For the pollutants $\mathrm{CO}, \mathrm{HC}$, and PM, the GTL/CCRT results are too small to include in the full model. Thus, the model for these pollutants includes only the unfiltered results. Because the effects of vehicle and test are confounded in the remaining data, it is not possible to separate the vehicle-to-vehicle variability from the test-to-test variability. Thus, the vehicle-to-vehicle variance component is removed from the model, and the remaining "test-to-test" variance component represents both test-to-test and vehicle-tovehicle variability. Comparisons between the unfiltered results are performed in the same manner as they are for the other pollutants. However, because the mean and standard error for the filtered results are essentially zero, we compare the means of the remaining two fleets to the mean for the filtered fleet by testing whether the $\mathrm{CARB} /$ none and GTL/none means are zero. We do this by constructing a $t$-statistic using the means and standard errors estimated by the model for these two fleets. The other exception to this approach involves the comparisons between the filtered and unfiltered results for PM under the NYCB cycle. In this case there are a few non-zero results for PM, though these results are still too small to include in a model. To compare GTL/CCRT with the other two fleets for NYCB PM, we use a two-sample $t$-test using the modeled mean and standard error for the CARB/None or GTL/None fleet and the sample mean and standard error for the GTL/CCRT fleet. 